\title{
الذكاي الحياتي ومعـوقاته لدى المعلمين الأوائل \\ بمرحلة التعليم قبل الجامعي
}

\section{عبر الحليم مخمد عبالحليم مدكور زاهر}

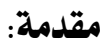

نظر الزيادة تأثنير ها في حياته اليوميـــة كمــــا

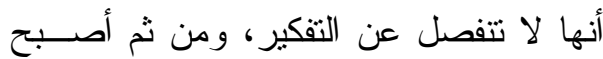
هناك اقتتاع تام بعـدم وجـــود الازدواجيــة

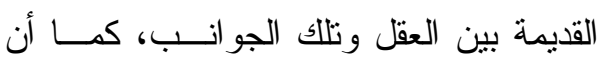

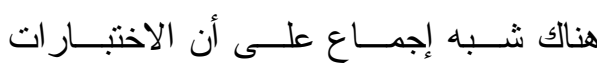
النقليدية للاككاء لن تعطي صورة متكاملة عن لهن سلوك الفرد و لا تمكننا من التنبؤ بنجاحه في نعي

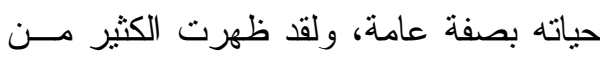
التساؤلات التي دعت إلى أهمية الربط بــين لئه الجانب المعرفي والجوانب الأخرى منها أنه

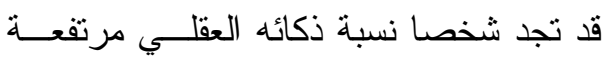

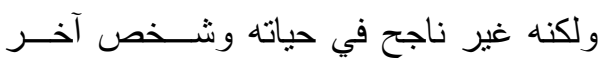
نسبة ذكائه متوسطة ولكنه ناجحاً في حياته،

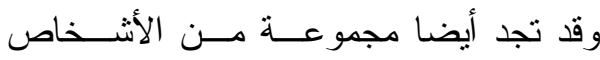

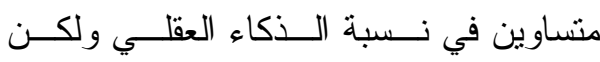
معدلات أدائهم غير منساوية، كل هذا قد دفع علماء النفس إلى البحث عن عنصر أو مجال

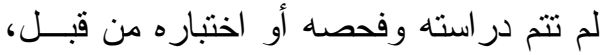

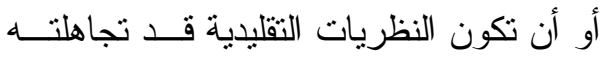
وعن طريقه يمكن تفسير كل هذه التتاقضات ألا و هو الذكاء الحياتي.

Feldman, ويـرى روث فيالــدمان أن اختبار ات نـسبة (R.D., 1997: 260)
تتاول عدد كبير من الدر اسات و الكتب

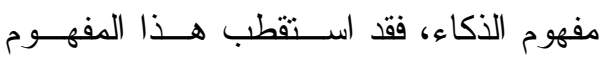
اهتمامات العلماء من شتى الميادين منذ أكثر

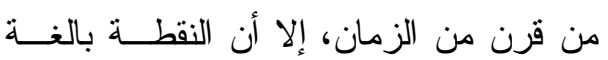

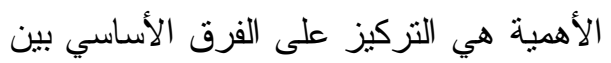
المفاهيم التقليدية و المفاهيم الأحدث للـــــــاء. وما زلنا نطالع نظريات جديـدة إلــى الآن،

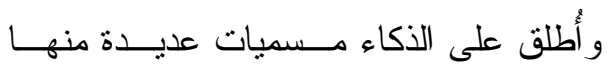

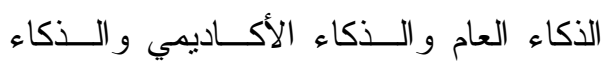
الموسيقى و الذكاء اللغوي و غير هــا، و وهـى ولـى جميعها تعبر عن الذكاء كما يقاس باختبار ات وعيرهات الذكاء التقليدية، ويأخذ الباحث بمسمى الذكاء

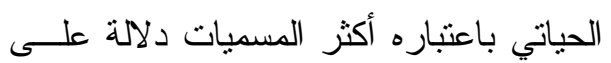

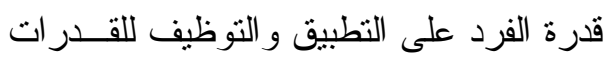
ووضع الأثياء حيز التنفيذ فى الحياة العملية ومو اجهة المشكلات الحياتية. ولم يعد الاهتمام بالنظرة التقليدية التي تتتاول موضوع الذكاء قاصر اً على المنظور

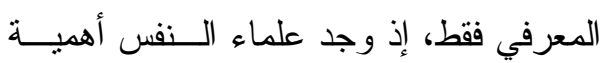

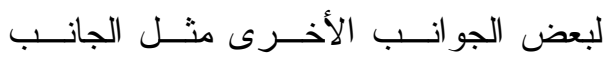

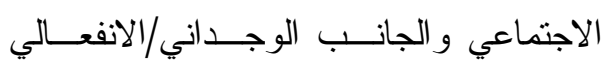
و الجانب العملي و أساليب التفكيـر للإنــسان 
وســالوفى) (Mayer and Salovey, 1997) ما يعرف بالذكاء الوجداني.

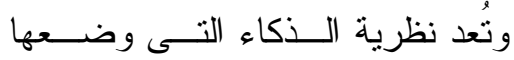

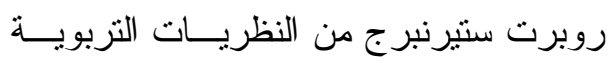

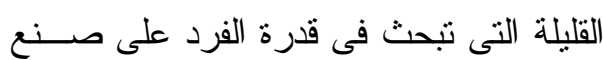

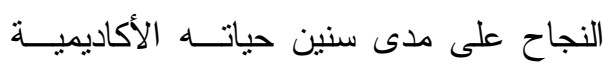
و العملية، وهي نوفر أساسا أوسع لفهم الذكاء

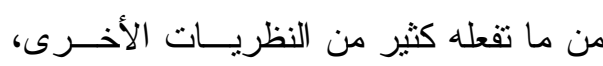

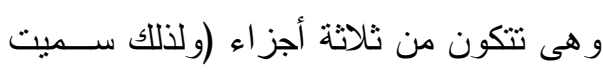

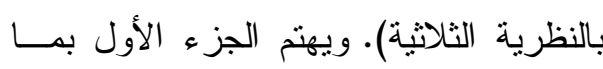
يحدث داخل الفرد- أي العالم الداخلي للفــرد

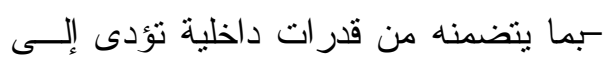
سلوك أكثر أو أقل ذكاء. ويهنم الجزء الثاني لقزي من النظرية بفحص خبرة الفرد فى التعامـلـل مع المهام و المواقف الحياتية، وتوجد نقــاط محددة فى أداء المهام بظهر فيها ذكاء الفــرد

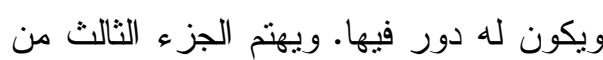

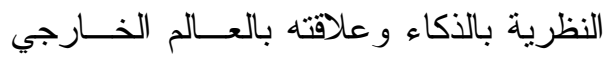

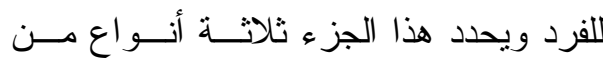
السلوك هي: التكيف البيئي، الانتقاء البيئـي لهي اعلئ

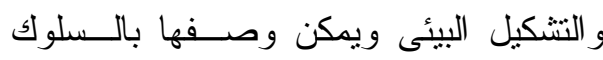

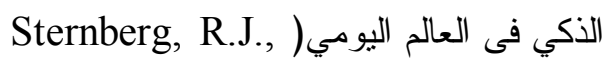
.(2003, Sternberg, R, J.2006

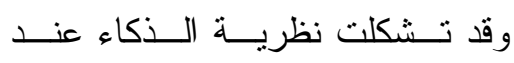

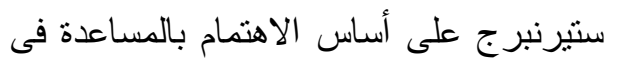

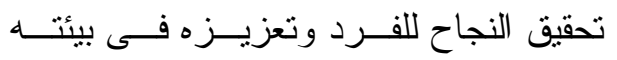

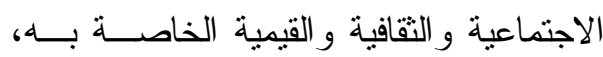

الذكاء التقليدية بها قصور شديد يتمثـلـ فــي

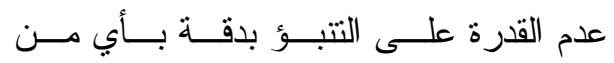

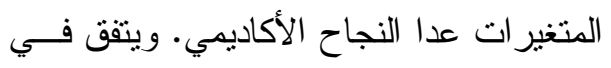
Epstein, S., and ذلك مع إيبشتين ومـاير (Meier, P., 1998:16) اختبارات الذكاء على الرغم من أنها بنيــــ

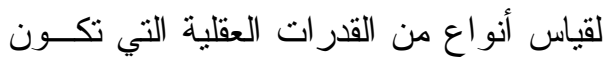

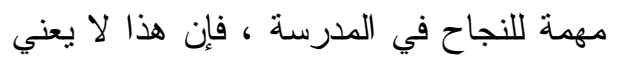

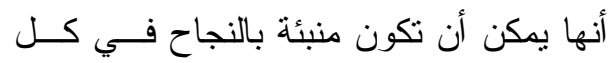
مجالات الحياة.

Goleman, D., ويـذكر جولمــان (1984:1) أن بعض علماء النفس قد بدأ في

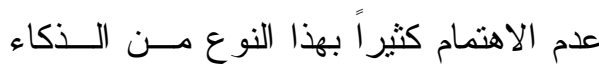

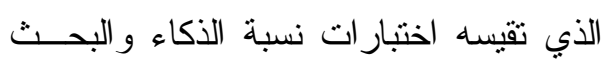
Gardner, H., عن غيره. حيث قدم جاردنر (1983) نظريته للأكاءات المتعددة، و التـي هي هي

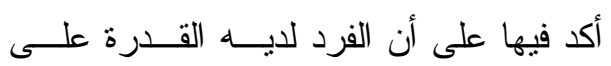

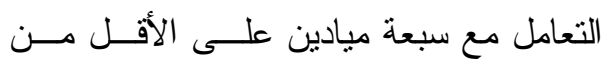

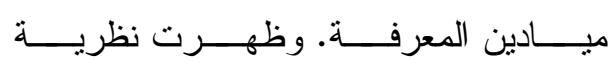
ســنـيرنبرج)(Sternberg, R.J., 2003) الثالثية في الذكاء، و التي تضم الذكاء العملي

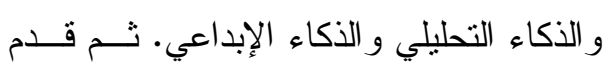
بيركنز (Perkins, D., 1995) نظرية الذكاء

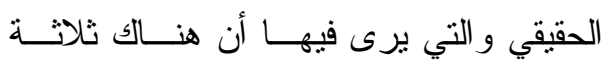

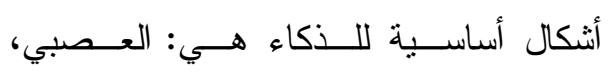

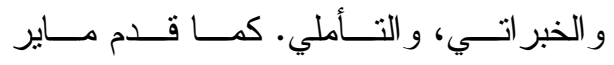


ومن الجدير بالذكر أن أهداف ومهــام

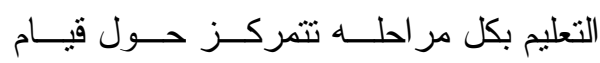

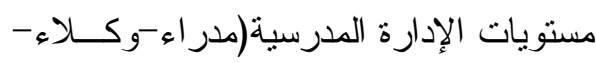

معلمون أو ائل) بمساعدة المتعلم في اكتـساب

معارف ومهار ات و اتجاهات تمكنه من تأدية

دوره بنجاح في حياته الأسرية، و المـشاركة

في الحياة العامة في مجتمعه و النجـــاح فــي

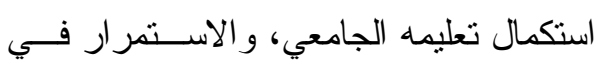

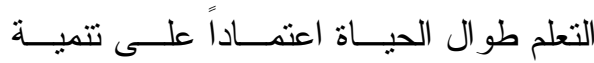

اســتر اتيجياته وقدر اتـــه لحــلـ المــشكلات

و الارتقاء بها لأنها الوسيلة المهمة لمساعدته

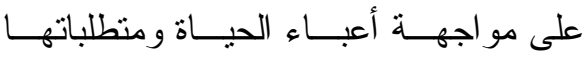

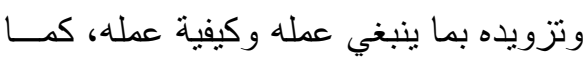

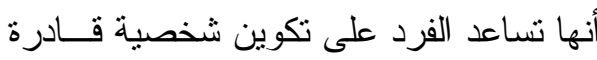

على العمل الجاد و المتميز و الإبـــداع و إدارة

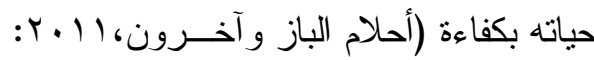

.$(\wedge$

وفى هذا الإطار تبدو ثمة علاقة وثيقة

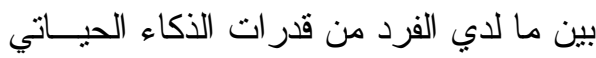

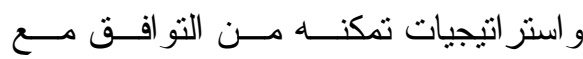
المشكلات الو اقعية من خلال التو ازن النسبي

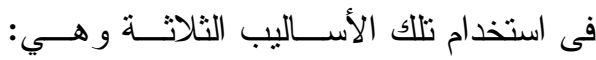
التكيف، و التشكيل، و الانتقاء وقدرته على حل

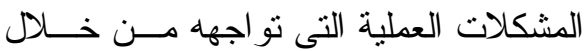

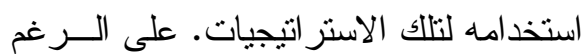
من أنه لا يمكن الادعاء بأن ذلك يحدث على الى

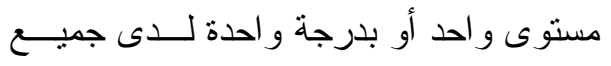

بحيث يستقفيد من استعداداته وقدر اته الخاصة

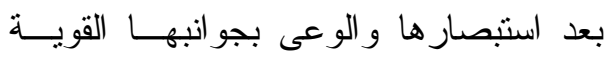

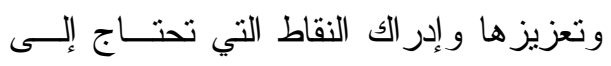
تعزيز ، وتقويتها لتمكنه من النجاح الذى يأمل

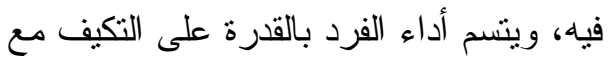

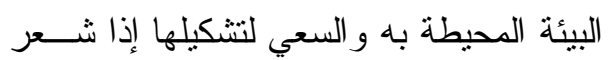

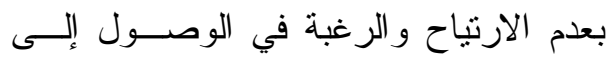

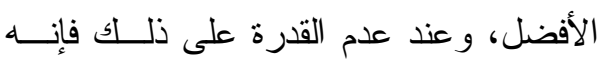

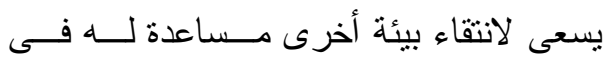

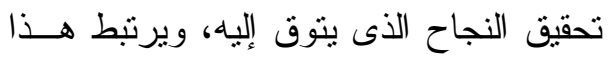

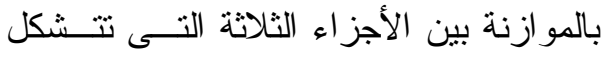

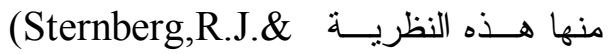
.Grigorenko E.L.,2002) وتوجد فروق فرديــة و اســعة بـين

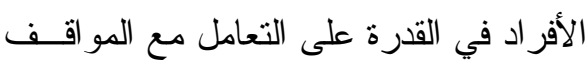

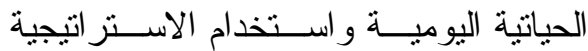

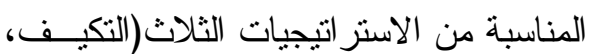

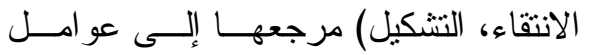
ومؤثرات عديدة، قد تتعلق بالقائم بالحل نفسه

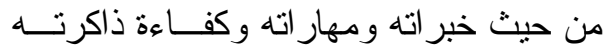
وفاعلية استر اتيجياته التي يستخدمها في حل المشكلات، ودافعيته و غير ها، وقد تتعلق هذه العو امل بالموقف المشكل ذاته من حيث بنيته ونركيبه وخصائص المعلومات المتضنة فيه

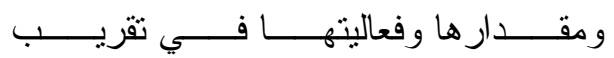
الحل(Bourne,et,al.,1971). 
وهناك مبرر آخر لمشكلة البحث فــي

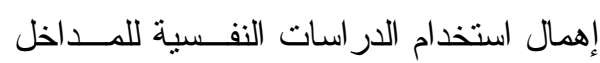
الحديثة لدر اسة الذكاء و التي تزكز كثير ا على

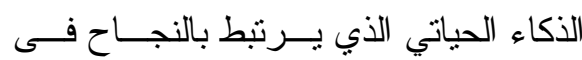

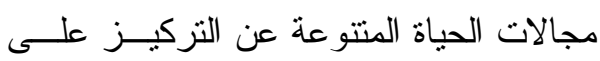
الأداء العقلي و الأكاديمي فقط. هذا وقد ثرتب على إهمال در اسة الــذكاء الحيــاتي عــدم الاهتمام باستخدام الأدوات الحديثة التى تقيسه

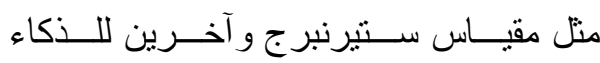
العملي، ذلك فى الوقت الذي تحرص فيه هذه الدراسـات على اســتخدام مقــاييس الــذكاء التقليدية و التي تزكز على الإجابات الصحيحة بدلا من التركيز على طرق حــل المــشكلة.

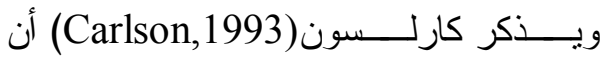
أساليب الذكاء الحياتي التي نشمل نكيف الفرد مع البيئة و انتقاء البيئة المناسبة ونتكيل البيئة لا تقاس بو اسطة معظم اختبار ات نسبة الذكاء وبالتالي فإنها ينقصها هذا الجانب المهم. كما يوجد مبرر آخر لمشكلة البحـــث في أن غياب معوقات الذكاء و عدم وجودهــــا ليس علامة تدل على الذكاء. ولكن وبدلا من

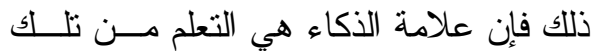
الأخطاء كي لا نقع فيها مر ات أخرى. فمـن

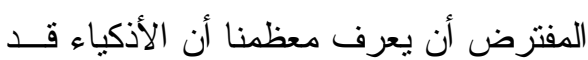
يكون لايهم معوقات الذكاء في أغلب الأحيان وقد يفشلون فى أداء ما يقومون بفعله أحيانــا

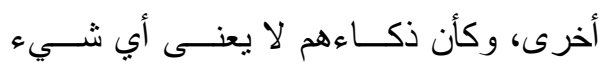

الأفر اد على تباين مستويات ذكــائهم، ومــن

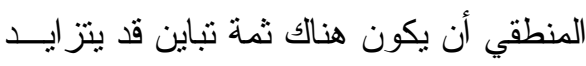
أو يقل فيما يتعلق بمستوى ذكاء الفرد، و أدائه

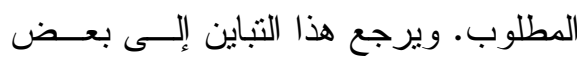
المعوقات أو المثبطات التى لا تمكن الفــرد من القيام بالأداء على المــستوى المناســبـ

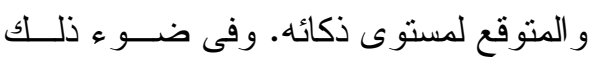
نشأت فكرة البحث الحالي.

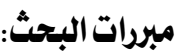

تبدو مبررات مشكلة البحث الحــالي في الحاجة إلى الكثف عـن طبيعـــة إدر الك المعلمون الأوائل في مرحلة التعليم الأساسي بحلقتيها الابتدائيـــة و الإعداديـــة و المرحلـــة الثانوية لمفهوم الذكاء الحياتي، ذلك أن إهمال تعرف هذا الجانــب مــن قبـــل الدر اســـات و البحوث النفسية يعوق دون إعــداد البيئــة التزبوية التي تساعد علــى تتميـــة الــذكاء

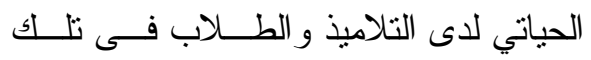

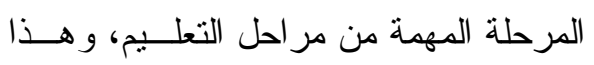

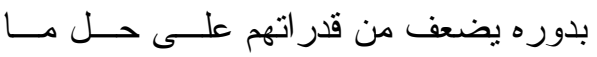
يو اجهرم من مشكلات فى العمل و أيضا فـى الحياة ويضعف من قدر اتهم على التعلم مــن تـن الخبرة و التكيف مع مو اقف الحياة المختلفــة من خلال التزكيز على الذكاء الحياتي الــذي يرنبط بالنجاح فى الحياة عن التركيز علـىى الأداء العقلي و الأكاديمي فقط. 


$$
\begin{aligned}
& \text { - ما درجة معوقات الذكاء الحياتي و أبعاده } \\
& \text { بالنسبة لهم في الحياة الواقعية، وأن الــذكاء } \\
& \text { لدى المعلمين الأوائل في مرحلة التعليم } \\
& \text { قبل الجامعي مقارنةً بمجتمعه؟ }
\end{aligned}
$$

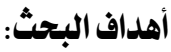

$$
\begin{aligned}
& \text { يـهف البحث الحالي إلى: } \\
& 1 \text { - وصــف أســاليب الـــكاء الحيــاتي } \\
& \text { باعتبار ها من الموضوعات الحيويــــة }
\end{aligned}
$$

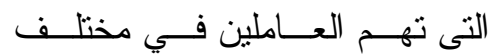

$$
\begin{aligned}
& \text { مؤسسات المجتمع وخاصة المؤسسات }
\end{aligned}
$$

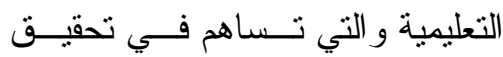

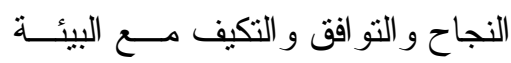

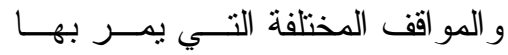

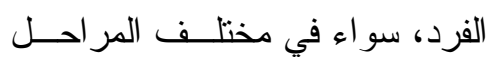

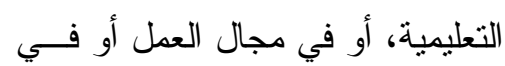

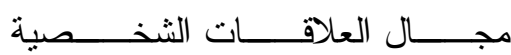

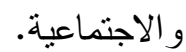

$$
\begin{aligned}
& \text { r- تحديد منوسطات درجات أبعاد الذكاء }
\end{aligned}
$$

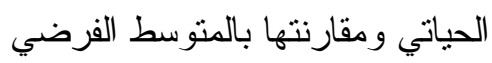

$$
\begin{aligned}
& \text { لمقياس الذكاء الحياتي. } \\
& \text { r- تحديد متوســـات درجــات أبعــاد } \\
& \text { معوقات الذكاء الحيــاتي ومقارنتهــــا } \\
& \text { بالمتوسط الفرضي لمقياس معوقـات } \\
& \text { الذكاء الحياتي. }
\end{aligned}
$$

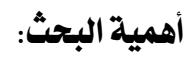

$$
\begin{aligned}
& \text { تكمن أهمية البحث في دراسة الـــكاء }
\end{aligned}
$$

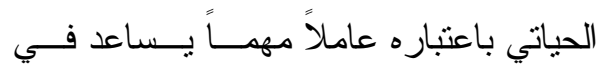

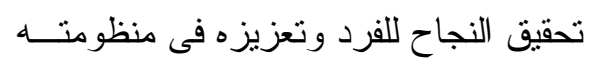

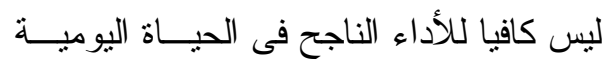

$$
\begin{aligned}
& \text { مهما كان تعريف هذا الذكاء. فمن الممكن أن }
\end{aligned}
$$

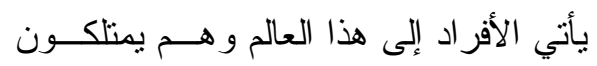

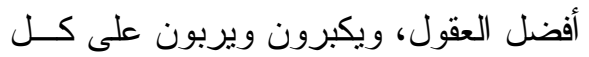

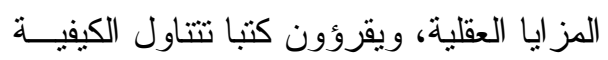

$$
\begin{aligned}
& \text { التى يكونون أكثر ذكاء من خلالها، ويظلون }
\end{aligned}
$$

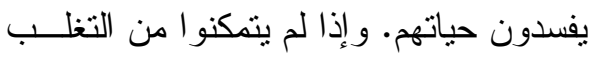

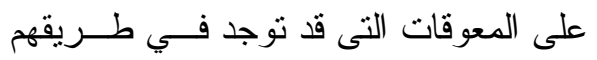

$$
\begin{aligned}
& \text { للأداء العقلي المثالي، فقد يجدوا أن ذكــاءهم }
\end{aligned}
$$

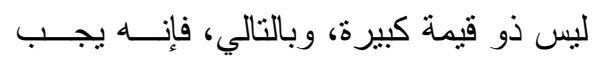

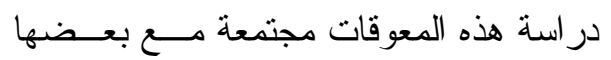

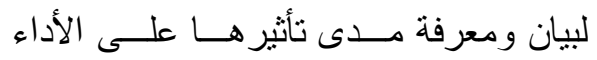

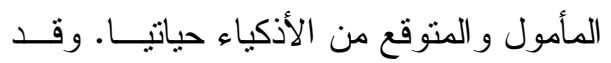

$$
\begin{aligned}
& \text { أكدت نتائج العديد من الدر اسات على وجود الادياء }
\end{aligned}
$$

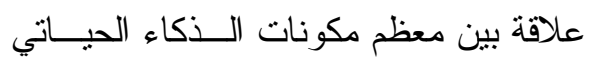

$$
\begin{aligned}
& \text { و التو افق النفسي و النجاح في الحيــــاة منهـــــا: } \\
& \text { در اسة بارك و آخرون(Park et al.,1997) }
\end{aligned}
$$

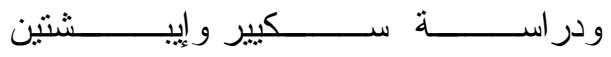

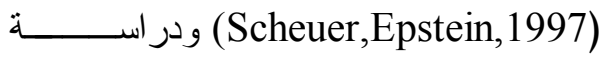

$$
\begin{aligned}
& \text { ستيرنبرج (Sternberg, R. J.,2000). } \\
& \text { مشكلة البحث: } \\
& \text { مما سبق عرضه يمكـن صــياغة مـشكلة } \\
& \text { البحث في التساؤلين التاليين: }
\end{aligned}
$$

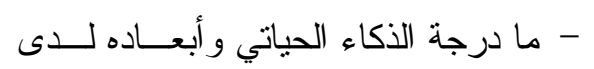

$$
\begin{aligned}
& \text { المعلمين الأوائل في مرحلة التعليم قبـلـل } \\
& \text { الجامعي مقارنةً بمجتمعهج؟ الاو هين }
\end{aligned}
$$


البيئة المحيطة به و السعي لنشكيلها إذا شــعر بعدم الارنياح و الرغبة في الوصــــل إلـى

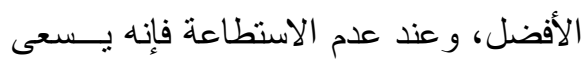

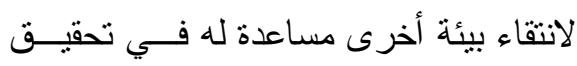
النجاح الذي ينوق إليه.

و هناك معوقات كثيرة من الممكن أن

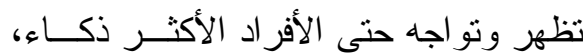
و هذه المعوقات ليست عقلية بــشكل كامــل، و إذا استطاع الأفراد أن يتحكمو ا فى منل هذه الأنواع من المعوقات، فهم حينئذ يستطيعون أن يركزوا على تتمية ذكاءهم مع إدر اكهــم

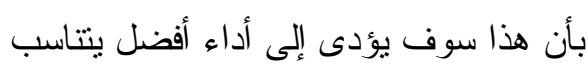
مع مستوى ذكائهم. وبالتالي، فإنه من المهـــ در اسة معوقات الذكاء الحياتي ومدى تأثنر ها على أداء الأفر اد في حل المشكلات العمليــة

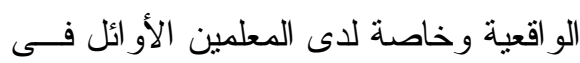
مرحلة التعليم قبل الجامعي. المصطلحات الإجرائية للبحث:

\section{Applied}

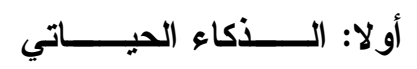

\section{Intelligence}

يُعرّق الذكاء الحياتي بأنــــه: الجهـــود

العقلية و السلوكية و الانفعاليـــة و الاجتماعيــة

التى يقوم بها الأفر اد كي يتو افقو ا مع البيئــة ولهـ

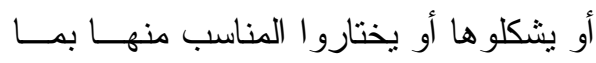
يساعدهم في حل المشكلات الحياتية الو اقعية

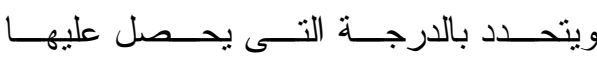
المفحوص (المعلمون الأوائل بمدارس مرحلة
الاجتماعية و الثقافية و القيمية الخاصـــة بـــه،

بحيث بستقيد من استعداداته وقدر اته الخاصة بعد استبصـار ها و الوعي بجو انبهــــا القويــــة وتعزيز ها و إدر الك النقاط التي تحتــاج إلــى تعزيز ، وتقويتها لتمكنه من النجاح الذي يأمل فيه، بما يجعل أداء الفرد متسماً بالقدرة على التكيف مع البيــــة المحيطــة بـــه و الـسعي لنتكيلها إذا شعر بعدم الارنياح و الرغبة في الوصول إلى الأفضل، وعند عدم الاستطاعة فإنه يسعى لانتقاء بيئة أخرى مساعدة له في

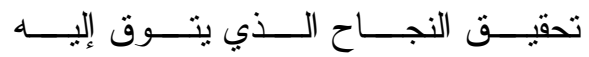
Sternberg,R.J.\&Grigorenko, E. (L.,2002). وكذللك تطبيق نتائج البحث فيما يتعلق بتحديد أبعاد الــذكاء الحيــاتي لــدى المعلمين الأوائل مقارنة بالمتوسط الفرضــي لمجتمعهم، وكذلك تحديد أبعاد معوقات الذكاء الحياتي لــدى المعلمــين الأو ائــلـل مقارنــــة بالمتوسط الفرضي لمجتمعهم. ويـشير ســتيرنبرج وجريجورينكــو

Sternberg, R. J. \& Grigorenko, E. (L.,2002) إلى أن الذكاء الحياتي يساعد في تحقيق النجاح للفرد وتعزيزه فى منظومتــه الاجتماعية و الثقافية و القيمية الخاصــــة بـــه، بحيث بستفيد من استعداداته وقدر اته الخاصة بعد استبصـار ها و الوعي بجو انبهــــا القويـــة وتعزيز ها و إدر الك النقاط التى تحتـــاج إلــى هـ تعزيز ، وتقويتها لتمكنه من النجاح الذي يأمل فيه. ويتسم أداء الفرد بالقدرة على التكيف مع 


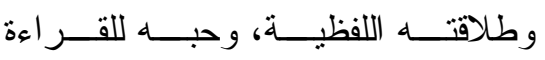

و الاطلاع، و الكتابة بكفـــاءة و إظهــــاره

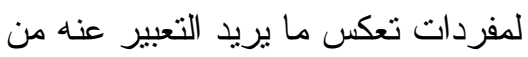

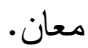

\section{Social}

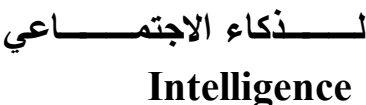

يُعرّف بأنه: مجموع استجابات الفــرد

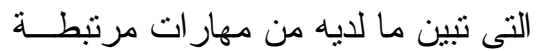

بإحساسه باحتياجات الآخرين ور غباتهم،

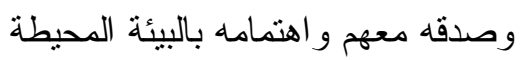

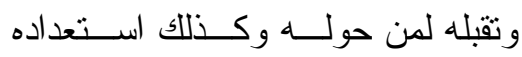

للاعتر اف بأخطائه.

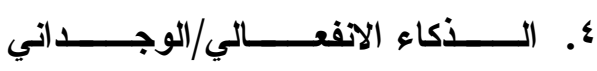

Emotional Intelligence

يُعرّت بأنه: مجموع اســتجابات الفــرد

التىى تنين ما لديه من مهار ات مرتبطــــة

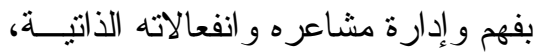

وقدرته على فهم انفعـالات الآخــرين

لتحقيق علاقات انفعالية إيجابية تـساعده

على التكيف السليم في المجتمــع الــذي

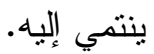

Analytical

ه. الـــــــاء التحليا

\section{Intelligence}

يُعرّف بأنه: مجموع استجابات الفــرد

التى تبين ما لديه من قدر ات على حـلـل

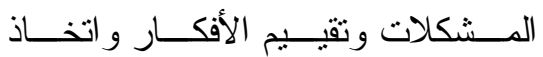

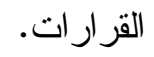

التعليم قبل الجامعي) في المقياس المعد لذلك.

ويشتمل على الأبعاد التالية:

Practical

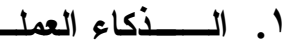

\section{Intelligence}

يُعرّت بأنه: مجموع استجابات الفــرد

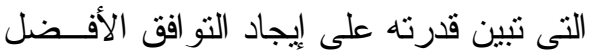

بينه وبين منطلبات البيئة من حوله ويتحــدد لهـد

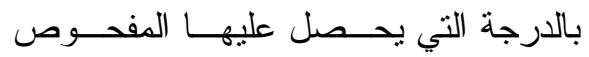

(المعلمون الأو ائل بمدارس مرحلة التعليم قبل

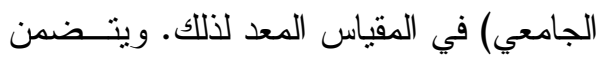

ما يلي:

أـ القدرة العملية على حـل المــشكلات:

تُعرّت بأنها: مجموع استجابات الفــرد

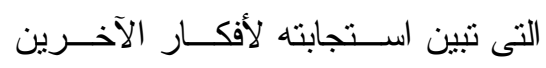

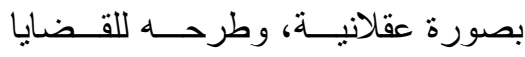

بصورة مثلى من خلال تحديد التز ابطات

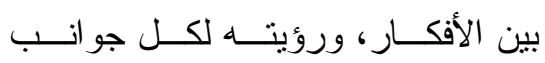

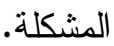

ب- قائمة المشكلات العياتية الواقعية:

تتضمن عدة مو اقف حياتية يومية، بعـد

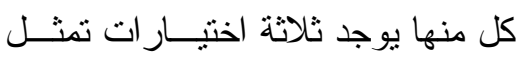

طرقا مختلفة لمعالجة الموقف الحيــاتي

$$
\text { يجب اختيار و واحد منها. }
$$

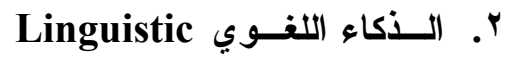

\section{Intelligence}

يُعرّت بأنه: مجموع استجابات الفــرد

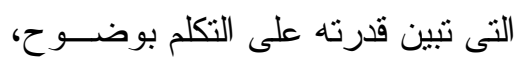


بأنه: منفتح على الأفكار و التطــــورات

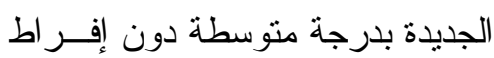

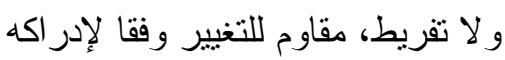

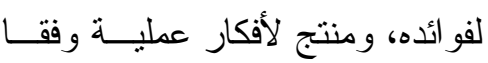
لاحتباجات الموقف. ب- أسلوب التفكير التحليلي: يُعرّت بأنه: درجة تفــضيل الفــرد للأنشطة التى تتطلب معلومات تستتد إلى الحقائق و التحليل، ويمتاز الفــرد في هذا الأسلوب بأنه: يحب العمل مع الحقائق ويتعامل معها بدقة وبطــرق

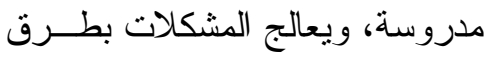
تخضع للمنطق و العقلانية، ويميل إلى لى لئن

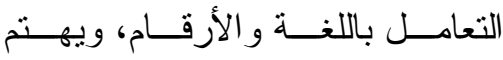
بالتعامل مع التقنيات. ج- أسلوب التفكير التنفيذي: يُعرّت بأنه: درجــة تفـضيل الفــرد للأنشطة المخططة جيدا و المتسلـــلة و المنتظمة و المعلومــات التفــيلية، ويمتاز الفرد في هذا الأسلوب بأنسـه: محـب للتفاصـيل، إجر ائسي، غيــر مخاطر ، محافظ ومحدد البنية. دـ - أسلوب التفكير الاجتماعي: يُعرّت بأنه: درجة تفــضيل الفــرد

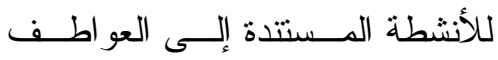
و الانفعالات و المشاعر ، ويمتاز الفرد
\. الأكاء المنطقي الرياضياتى-Logical

\section{Mathematical Intelligence}

يُعرّق بأنه: مجموع استجابات الفـــرد التى تبين قدرته على معالجة الـسـلاسل من الحجج و البر اهين و الوقائع للتعــرف على أنماطها ودلالاتها، وذلك باستخدام العلاقات المجردة وتقدير ها.

Thinking Styles أساليب التفكير V

تُعرّت بأنها: مجموع استجابات الفــرد التى تبين طرقه المفضلة في التعبير عن

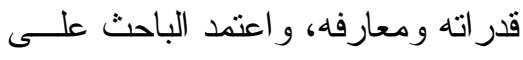

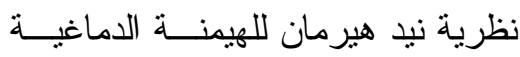

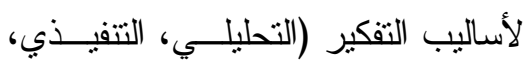
الاجتماعي، الإبداعي)، و على مقيــاس الاس

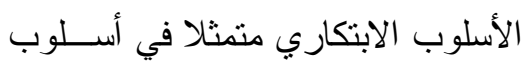

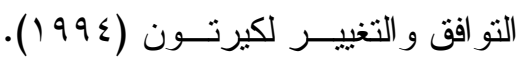
وتتحدد بالدرجة التــى يحـــل عليهـــا

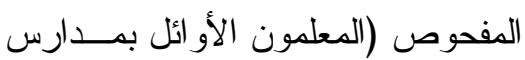
مرحلة التعليم قبل الجامعي) في المقياس المعد لللك. وتتشتمل على الأبعاد التالية: أ- أسلوب تفكير التو افق والتغيير: يُعرّت بأنه: درجة تفــضيل الفــرد للاستقر ار و الاســــمر ارية و التغييــر

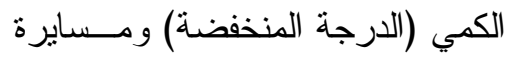
التطور ات الجديدة و التفكير الأحسـدث

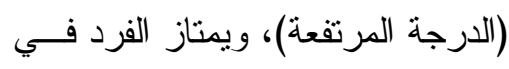

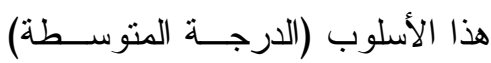




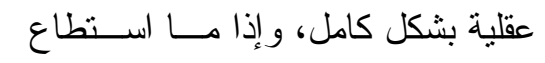

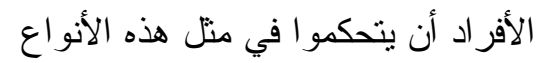

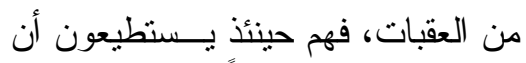

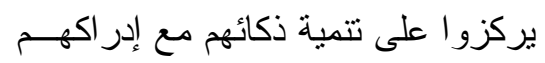

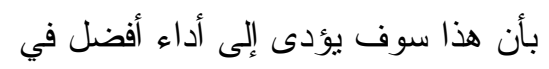
الحياة الو اقعية. وبذلك، فإن الفرد الــذي لــي

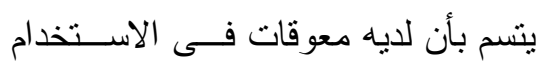

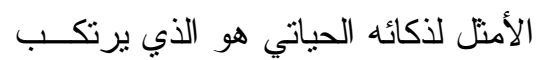

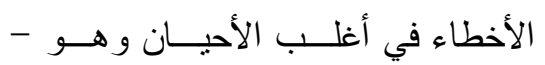
أيضاًا الذي يفشل في أداء ما يقوم بفعله الأن

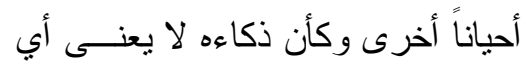
شيء بالنسبة له في الحياة الو اقعية:

\section{ا . نقص الدافعية Lack of Motivation}

يُعرّق بأنه: مجموع اســتجابات الفــرد التي تعكس مدى اقتتاعه بـــأن الدافعيـــة ليست مصدر اللفروق الفردية في النجاح وأن نجاحه منوقف على مدى تقاعله مع لئد المهام و المو اقف الحياتية.

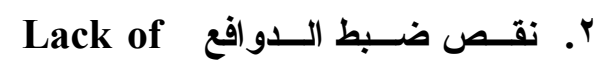
impulse control

يُعرّف بأنه: مجموع استجابات الفــرد التي تعكس سلوكه الاندفاعي و التهورى

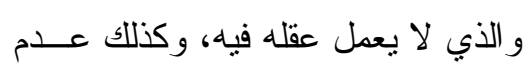

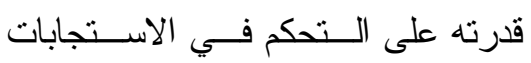

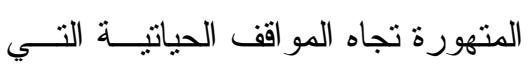
يتعرض لها.
في هذا الأسلوب بأنه متعاطف ولديه حس تجاه الناس، وينزع إلى الحقائق

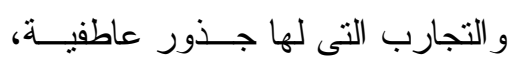
ويمنالك القدرة على اســتعمال اللغـــة

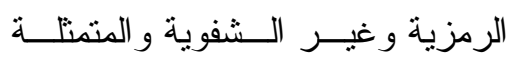
بمهار ات الاتصال عن طريــق لغـــة الجسد و الأعضاء، ويعالج المشكلات بطرق عاطفية وليس بطريقة منطقية. ه- أسلوب التفكير الإبداعي: يُعرّف بأنه: درجـــة تفــضيل الفــرد

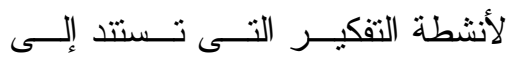
المفاهيم و النظرة الكلية، ويمتاز الفرد فى هذا الأسلوب بأن لايه: حسـاسية

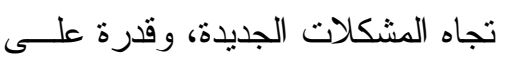

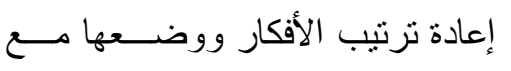
بعضها البعض بطرق وتر اكيب غير مألوفة، و لا يميل إلى عمل الأثــياء

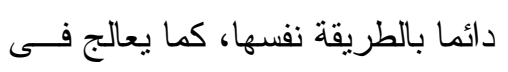

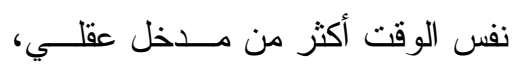
وييتكر أفكار ا وطرقا وأدوات جديدة.

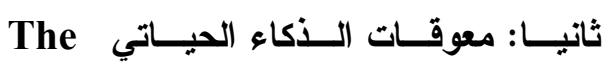
Blocks Of Applied Intelligence تُعرّت معوقات الذكاء الحياتي بأنها: تلك

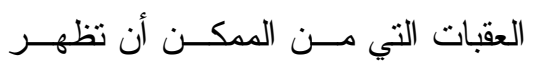

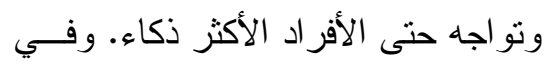

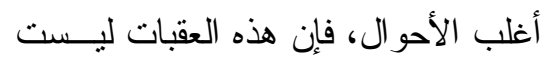


؟. نص التكيف مع الظروف والأوضــاع

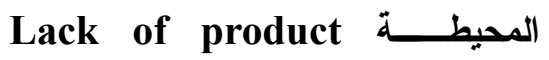
orientation

يُعرّت بأنه: مجموع اســتجابات الفــرد

التي تبين عدم اهتمامه بالنتائج النهائيـــة

لأي عمل يقوم بــه، وفقدانــــه الانتبـــاه

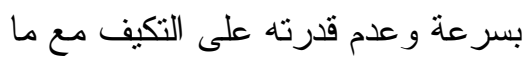

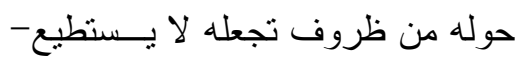
غالبا-إنجاز أي شيء مكلف به.

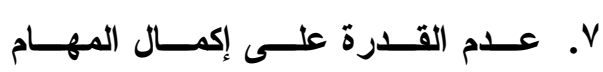

ومواصلتها حتى الإنجاز

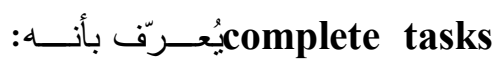

مجموع استجابات الفرد التي تبين عجزه بدرجة ما عن إتمام و إكمال أب مهمـــة

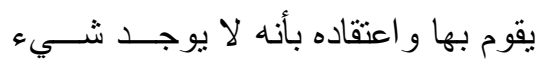
يمكن أن يصل إلى نهايته وذلك بـسبب

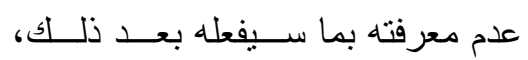
وخوفه من الوصول للنهاية.

A. الفشل فـي المبــادرة مول Failure to initiate

يُعرّف بأنه: مجموع استجابات الفــرد

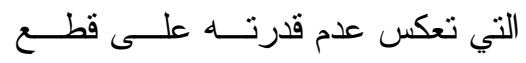

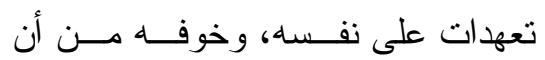
يصبح مقيدا ضمن إطــار معـين لأي وخي

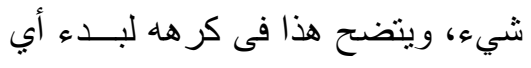

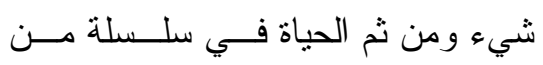
العلاقات السطحية. rا نقص المثابرة/المثابرة المفرطة Lack of perseverance and excessive perseverance

يُعرّت بأنه: مجموع استجابات الفــرد

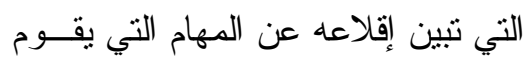
بها بسرعة وبسـهولة بالر غم من ذكائســا

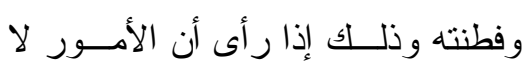

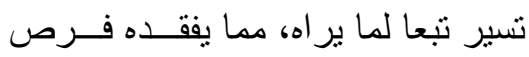
كثيرة للنجاح ويجعله عرضة للإحبــاط لئاط و الفشل.

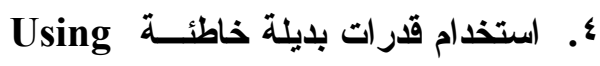
the wrong Abilities

يُعرّق بأنه: مجموع اســتجابات الفــرد

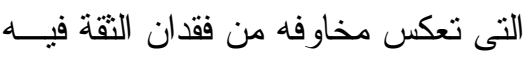

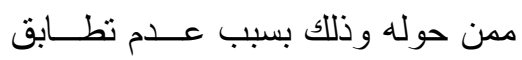

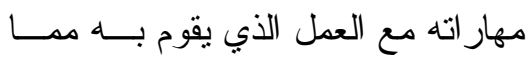
يضطره إلى تغيير مجاله المهني.

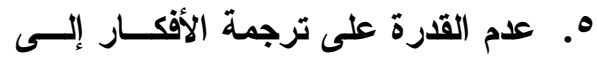

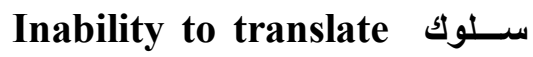
thought into action يُعرّف بأنه: مجمو ع اســتجابات الفــرد

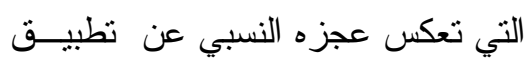

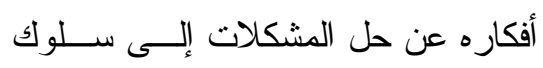
عملي و اقعي وذللك لتفضيله الثبوت عند الفكرة فقط دون القيام بأي خطوة عملية لتطبيقها. 
يُعرّت بأنه: مجموع اســتجابات الفــرد

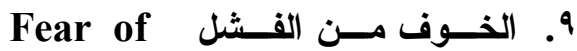

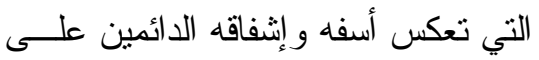

Failure

ذاته مما يجعل الآخرين يغضبون منــهـ

يُعرّف بأنه: مجموع اســتجابات الفــرد

و لا بتعاونون معه لفشل توقعاتهم في أن

التي تعكس عدم وصوله إلى الاستخدام

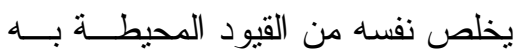

الكامل- نسبيا -لقدر اته العقلية بـسبب

و النجاح في كل ما يقوم به.

خوفه من مخاطرة عدم النجاح في أمور

با 1 الاتكالية المفرطة (التبعيــة الزائــدة)

محدودة ومحددة مما ينعكس على عـدم

Excessive Dependency

يُعرّت بأنه: مجموع اســتجابات الفــرد

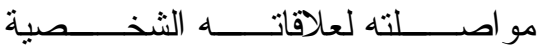

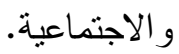

التي تعكس اعتماده على الآخرين فــي

معظم المهام التي يو اجهها، وأن يتحمل التمل

• 1 ـ التـــــويف (الإرجــــاء و المماطلـــة)

Procrastination

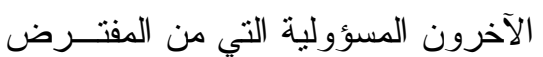

يُعرّف بأنه: مجمــوع اســتجابات

أن يتحملها هو ، وذللك في إطار من عدم من لان

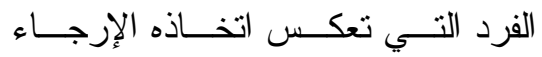

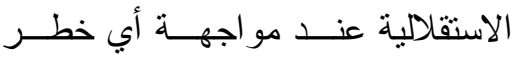

و المماطلة كطريقة تقليدية معتادة لفعـل

"يهدده."

الأشياء، و عدم قدرته على فعلها دون أن

؛ 1.الاغغماس في الصعوبات الثخــصية

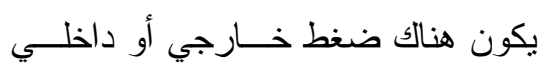

Wallowing in Personal

مفروض من الفرد نفسه.

Difficulties

يُعرّف بأنه: مجموع استجابات الفــرد

التي تعكس عدم قدرته علـــى مر اعاتــهـ

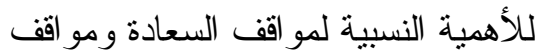

الحزن في حياته، وأن يجعل صـــوباته

الشخصية تطغى على العمل الذي يقــوم

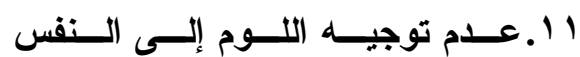

Misattribution of blame

يُعرّت بأنه: مجموع اســتجابات الفـرد

التي تعكس اتجاه الفرد نحو توجيه اللوم بعربات

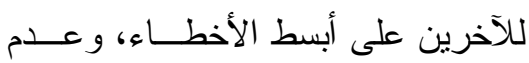

توجيه اللوم إلى الذات مما يقف عائقـــا

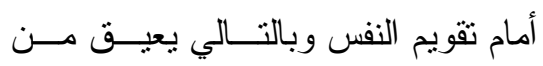

ه ـ القابلية لتحــول الانتبـاه بـسرعة

استخدام كل مو اهبه إلى الحد الأقصى.

Distractibility

يُعرّق بأنه: مجموع استجابات الفــرد

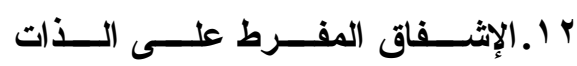

Excessive Self-Pity

التي تعكس عدم قدرته علــى التركيــز 


$$
\begin{aligned}
& \text { تعكس تجاهله للصورة الكلية للأثـــياء } \\
& \text { و انشغاله بأدق التفاصيل و إهماله التفكير } \\
& \text { فى معنى ومضمون ما يقوم بـــه مــن ولند }
\end{aligned}
$$

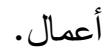

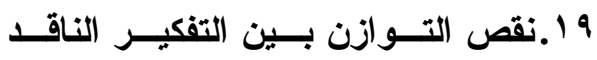

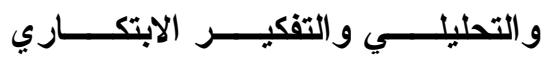

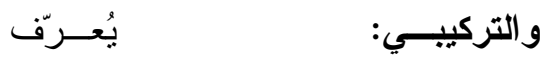

$$
\begin{aligned}
& \text { بأنه: مجموع استجابات الفرد التي تبين } \\
& \text { ضعف قدرته على تحديد نمط التقكيــر }
\end{aligned}
$$

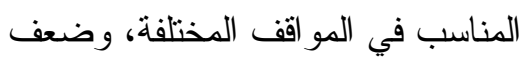

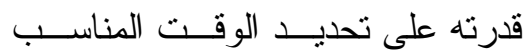

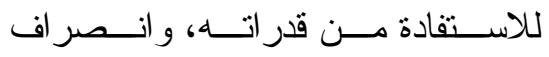

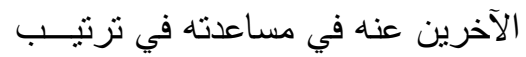

$$
\begin{aligned}
& \text { المهام التي يقوم بها. }
\end{aligned}
$$

• • . المستوى الأعلى والمستوى الأقل للثقة

بالنفس

$$
\text { Sيُعــــــelf-confidence }
$$

مجموع استجابات الفرد التــي تعكـس اضطر اباً في الثقة بنفسه و أنها لا تمثتلـل فئل شيئا في تقديره لذاته وقدر اته و التي تنين عجزه عن الموازنة بين الثقـــة الز ائـــدة

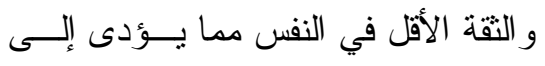
الفثل غالبا فيما يقوم به من مهام.

دراسات سابقة:

فيما يلي يعرض الباحــث أهـــم الاراســات السابقة ذات العلاقة بموضوع البحث.
على شيء و احد لمدة طويلة، و انخفاض الاضن

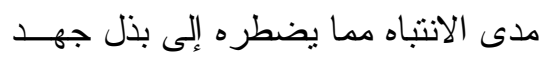
ما لترتيب بيئة العمل بقدر المستطاع.

1 ا ـالقدرة على توزيع الأعمــال بــصورة

متباعدة جدا وبصورة مكثفة جدا:

Being spread too thin or too thick

يُعرّق بأنه: مجموع اســتجابات الفـرد

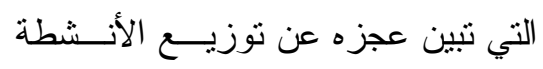

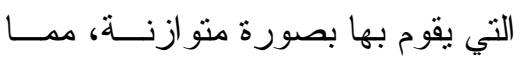

يتسبب في دخوله في الكثير من المهــام

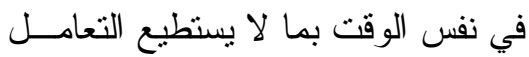

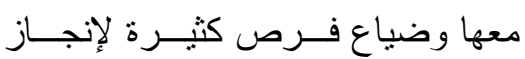

معظمها.

IV ـ عدم القــدرة علــى تــأخير الإثـــاع

و الإرضــاء Inability to delay

gratification

يُعرّت بأنه: مجموع استجابات الفــرد

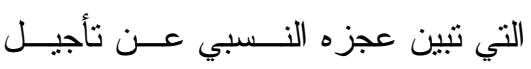

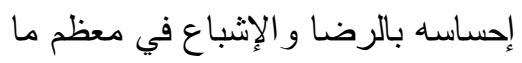

يقوم به، وتجنبه الدخول في مهام طويلة

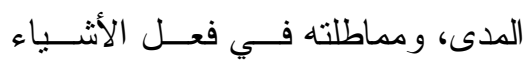

$$
\text { الكبيرة و الصغيرة. }
$$

1 ا.عدم القدرة على رؤية الأشياء بصورة

كلية وشــاملة: Inability to see

the forest for the trees

بأنه: مجموع اســتجابات الفـرد التــي 


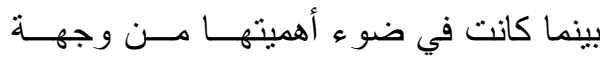

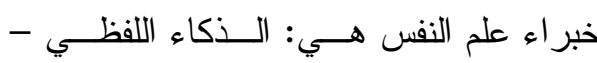
القدرة على حل المشكلات.

كما هدفت دراســة نجـــي ونــيس حبشي ورأفت عطية بــاخوم(1991) إلــى

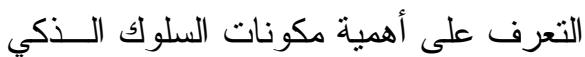

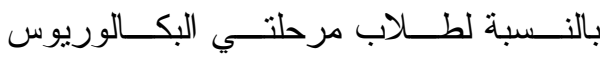

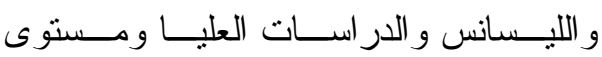
الطلاب مرتفعي المستوى في أحد مكونــات السلوك الذكي في المكونات الأخرى، وطبيعة الفروق في إدر الك مكونات السلوك الذكي بين

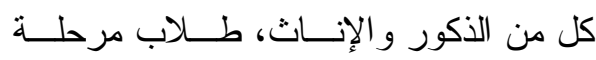

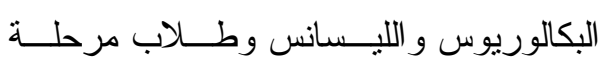

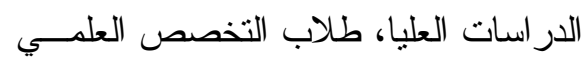

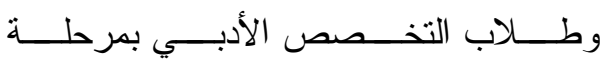

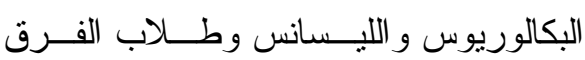

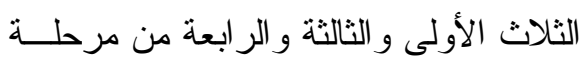

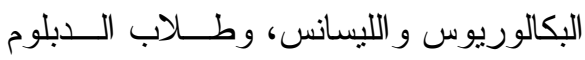

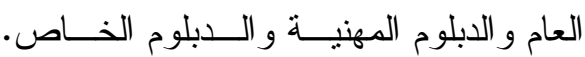
وتكونت العينة من (r (T) طالبا بكلية التربية بالمنيا. و واستخدمت قائمة السلوك الذكي و غير

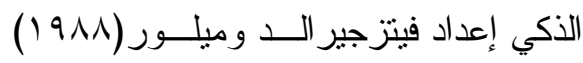
وترجمها و أعدها للبيئة المــصرية الباحثــان

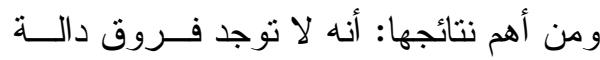

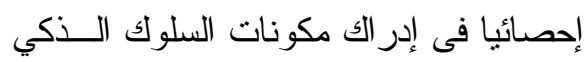

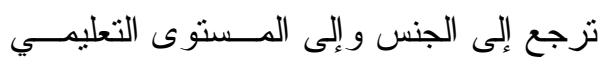
و إلى متغير التفاعل الثنائي بينهما. كما أنه لا لا لريل
هدفت دراسة فيتزجير الــــ ومياــور

Fitzgerald, J.M.\& (Mellor,S,1988

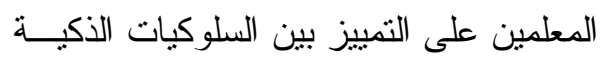

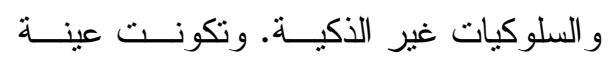
الدر اسة من (ب 9 (1) معلما. و استخدمت قائمة

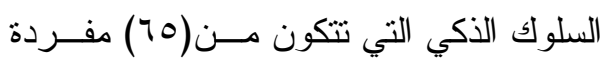

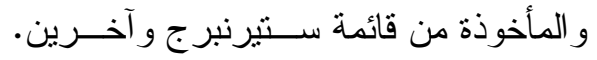
وكــشفت النتــائج عــن تمييــز المعلمـــين السلوكيات الذكية و السلوكيات غير الذكيـــة،

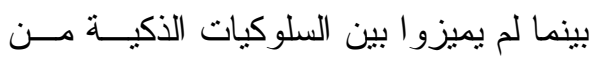
حيث الأهمية، وأن السلوك الذكي يتكون من بن

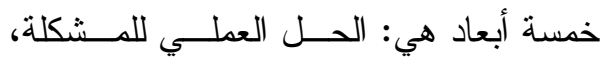

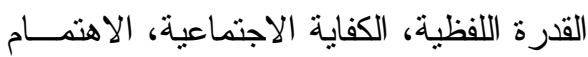
بالتعلم و الثقافة، و الصفة المميزة.

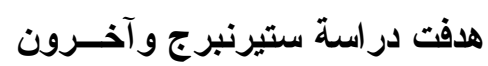
إلى التعرف(Sternberg,et.al,1995a): على أهمية مكونات السلوك الذكي بالنـسبة لكل من خبر اء علم النفس و المهنيين وشملت

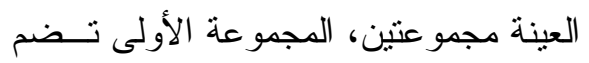

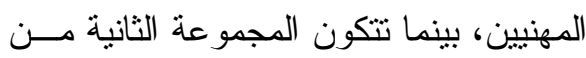
خبر اء علـــم الــنفس. و واســتخدمت قائمـــة ستيرنبرج و آخرين و التي تتكون من (ro. عبارة لقياس السلوك الذكي. و أظهرت النتائج أن مكونات السلوك الذكي لعينـــة المهنيــين حسب أهميتها هي: القدرة على الحل العملي

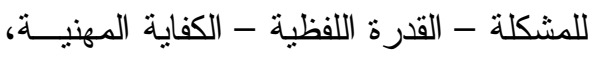


وهدفت دراسة ســـيد عبــــ الغتــي

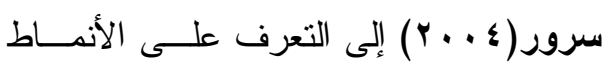

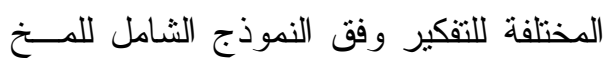

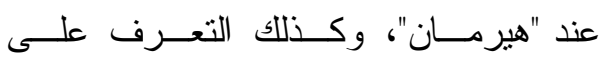

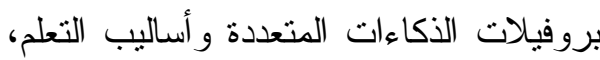
و هدفت أيضا إلى الوصف الكمي للعلاقة بين أنماط التقكير وكل من الـــكاءات المتعــددة و أساليب التعلم و إلى التتبؤ بنمط التفكير وفق وفن تصور "هيرمان" للمخ من خــلال الـــكاءات

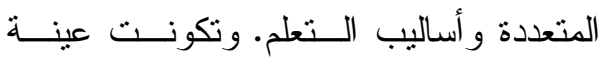
الدراسة من(0 • 1) طالب من طلاب الــدبلوم

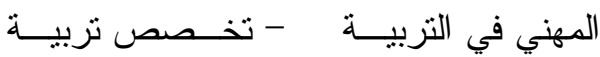

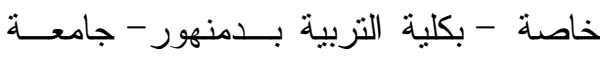
الإسكندرية. وقد استخدم الباحث عدة أدوات

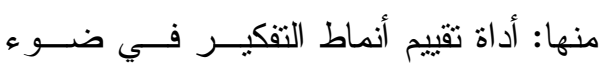

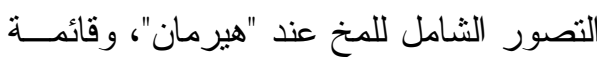

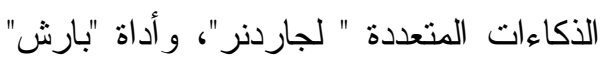
لتقييم الأسلوب المفضل في التعلم. وكـشـفت النتائج عن: وجود علاقة دالة إحصائيا بــين

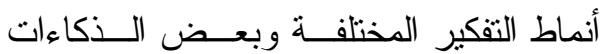

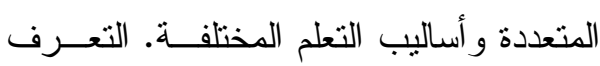
على بروفيلات الذكاءات المتعددة وأســاليب التعلم المفضلة لدى عينة الدراسة. إمكانيــة

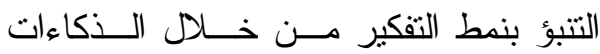
المتعددة و أساليب التعلم.

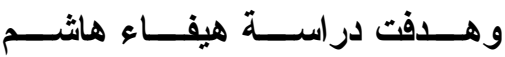

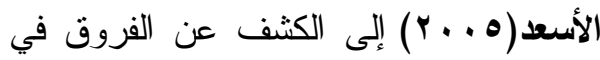

توجد فروق دالة إحصائيا بين الفرق الــثلات الأولى و الثالثة و الر ابعة في إدر الك مكونـــات

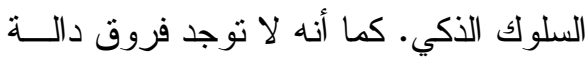
إحصائيا بين طلاب الدبلوم العــام و الــدبلوم المهنية و الدبلوم الخاص في إدر الك مكونــات

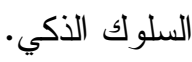

وهــدفت در اســـة الــسيد إبـــر اهيم

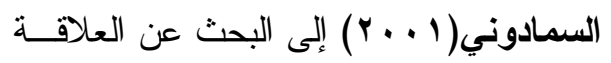

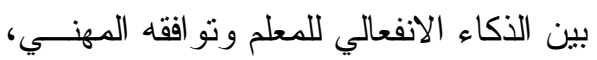

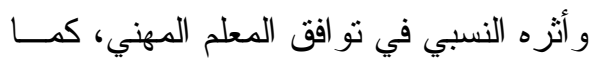

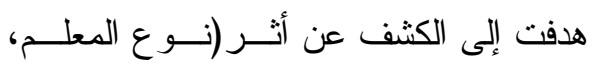

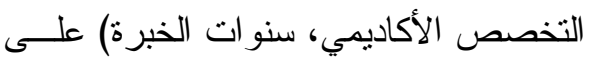

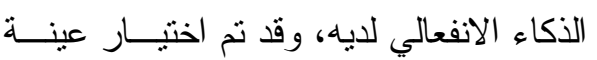

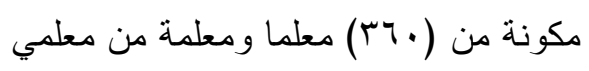

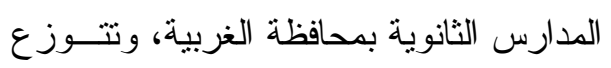

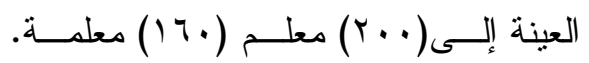
وتوصلت النتائج إلى وجود علاقة ارتباطيــة موجبة دالة إحصائيا بين درجــات مقيــاس ونساس

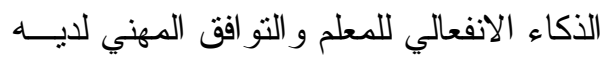

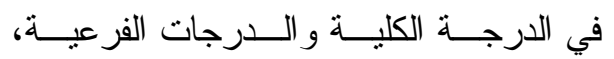
و أوضحت النتائج وجود فروق الجنسية فــي الذكاء الانفعالي و أبعاده الفرعية بصفة عامة وروفة لنئيه

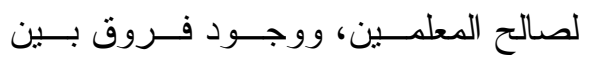

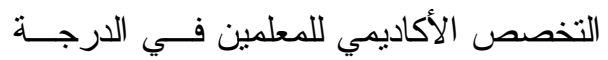

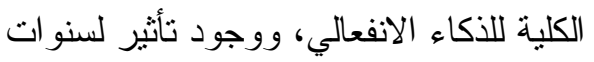
الخبرة على الدرجة الكلية للذكاء الانفعالي. 
التعليمية الثناثة، واستخدمت الدراسة قائمــة

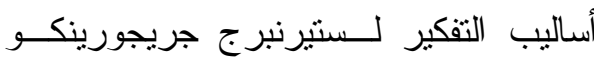
تزجمة عبدالمنعم الدردير ، و أوضحت النتائج أنه لا توجد فروق ذات دلالة إحصائية فــي

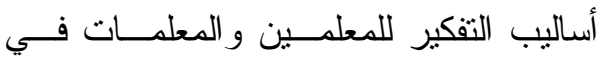

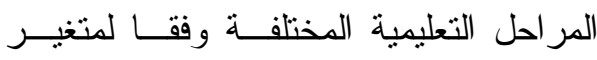

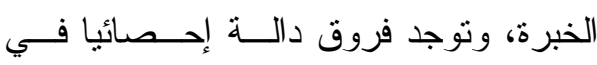
أساليب التفكير لدى المعلمين و المعلمات وفقا دون لللنوع ، وتنستخدم المعلمات أســاليب تفكيــر متتو عة في التدريس مقارنة بالمعلمين وهدفت دراسة راثد الكايــ(^ . . ץ)

إلى التعرف على درجة الــــكاء الاجتمـــاعي

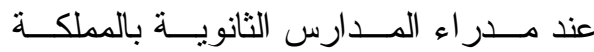

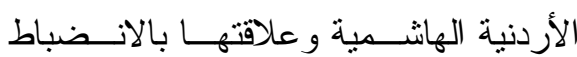

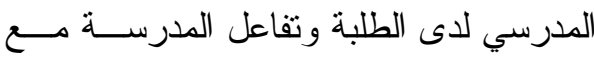
المجتمع المحلي من وجهة نظر المعلمـين، ونهي، حيث نم اختيار العينة بطريقة عشو ائية وكان

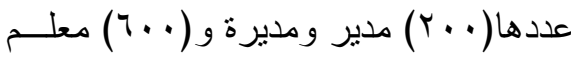
ومعلمة، ولقد استخدمت استبانة لقياس درجة

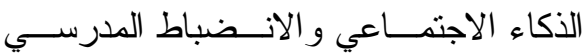

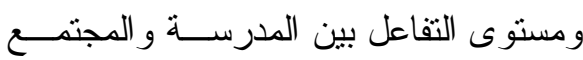
المحلي، وبعد استخدام الأساليب الإحــصائية

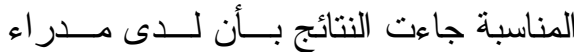

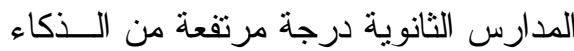
الاجتماعي، وأن هناك علاقة دالة إحــصائيا

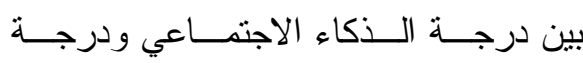
الانضباط المدرسي لدى المــدر اء، كـــــا أن
الذكاء الوجداني بين المعلمات و المتغيــرات المستقلة (مستوى الأداء الوظيفي، ســنوات التهئ

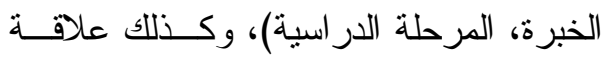
الذكاء الوجداني بـسمات الثخـصية بــين

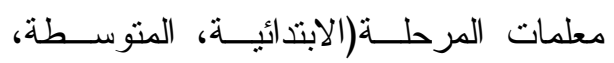
الثانوية) بمنطقة صفوي بالمملكــة العربيــة

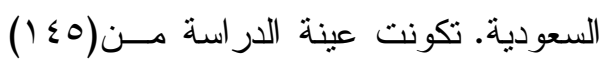

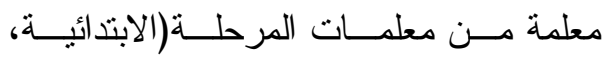

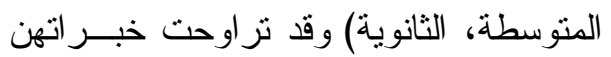

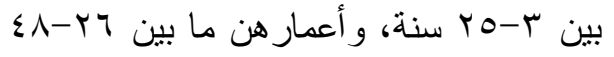

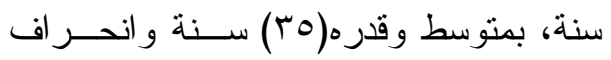
معياري(r, (0). ونم استخدام مقياس الـــكاء

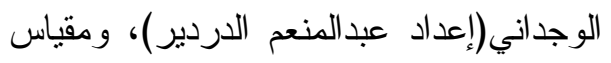
التحليل الإكلينيكي (الجزء الأول) الــذي قـــام

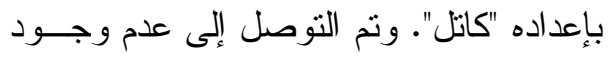

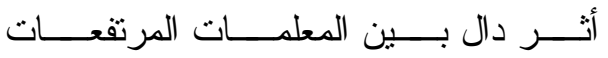

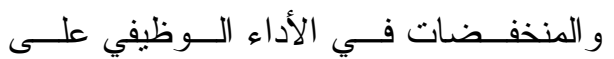
المقياس الكلي و المقــاييس الفرعيــة للــــكاء

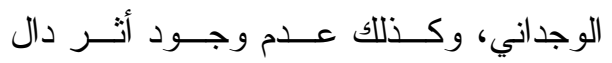

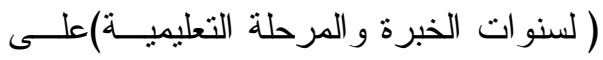
المقياس الكلي و المقــاييس الفرعيــة للــــكاء الوجداني. وهدفت دراسة حاسـن بـن رافــع

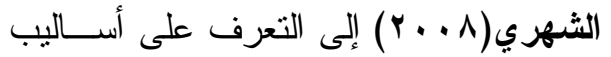

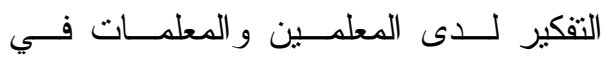
التدريس، وتكونت عينة الدراسة من (YTV)

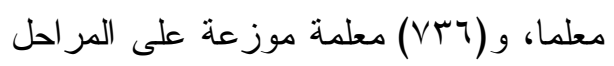




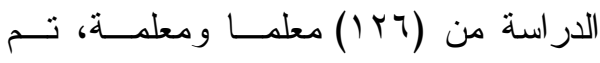

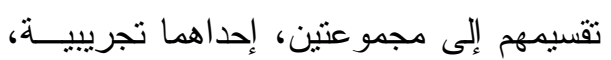

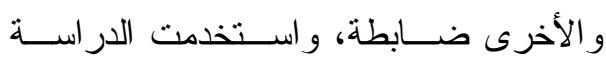

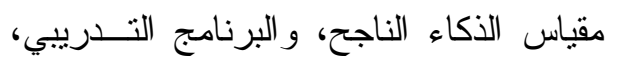
وتوصلت النتائج إلى وجود فروق ذات دلالة

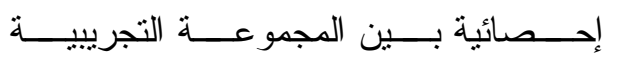
و المجموعة الضابطة في القياس البعدي على لى لئ لئل

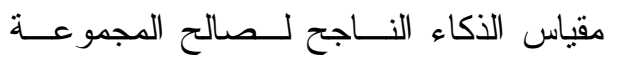

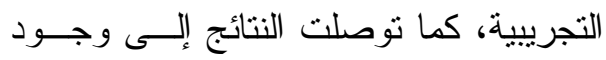
فروق ذات دلالة إحصائية لدى المجموعــة لونة

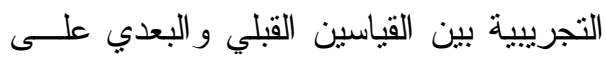
مقياس الأكاء الناجح.

\section{تعليق عام على الاراسات السسابقة:}

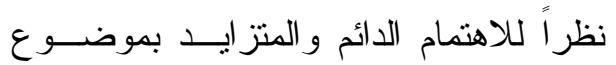

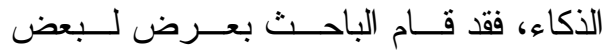

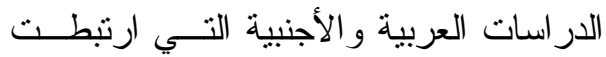

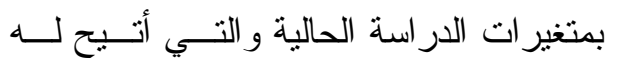
الاطلاع عليها و التي تتاولت نظرية الــذكاء

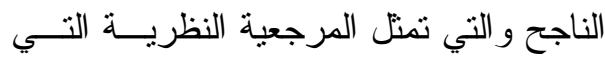
اعتمد عليها الباحــث فــي بنائـــهـ للإطــــار النظري، و أدوات البحث، وتفسير النتائج التي لني

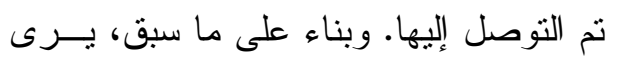
الباحث أن البحث الحالي و الذي يهدف إلـى

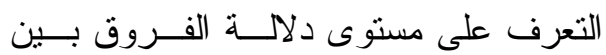
المتوسط الفعلي للمجتمع والمتوسط الفرضي

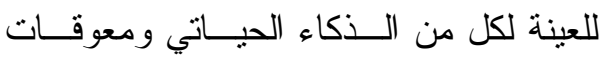
الذكاء الحياتي قد اختلف عـن غيــره مــن
هناك علاقة دالة إحصائبا بين درجة الــذكاء للمدير ودرجة التفاعل مع المجتمع. كما هدفت دراسة ناصر عبداله محمد

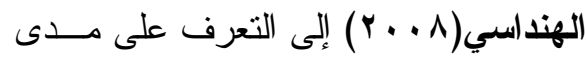
تو افر الذكاء الانفعالي لاى مدر اء المـــدارس

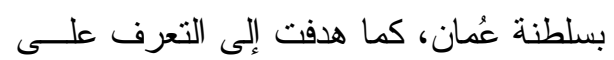

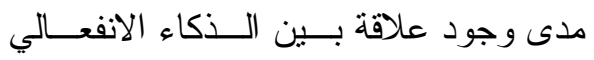

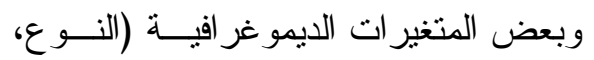

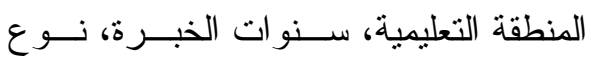
المدرسة) وتم استخدام مقياس جولمان للذكاء

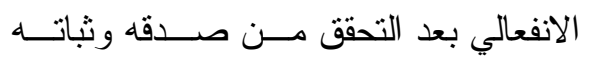

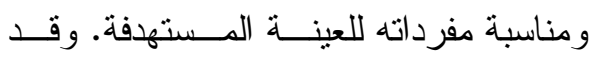

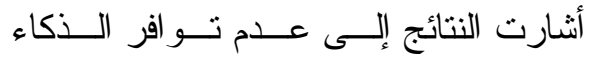

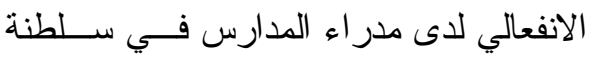
عمان بشكل مرتفع. وكانت الفــروق دالـــة إحصائيا في بعد المهار ات الاجتماعية لصالح المدر اء ذوي الخبرة الطويلة مقارنة بـذـوي بـاني

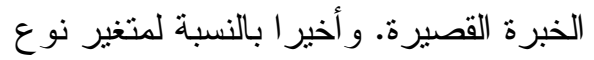
المدرسة(ابتدائي، متوسط، ثــانوي)أثنـارت النتائج إلى وجود فروق دالة في ثلاثة أبعـاد

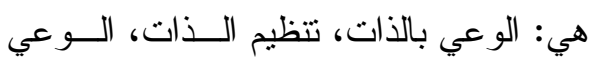
الاجتماعي لصالح مدر اء الحلقة الابتدائية. وقد هدفت دراسة يوســف محمــود

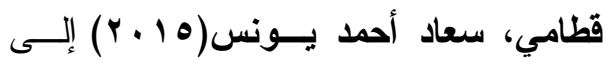

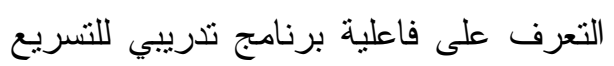

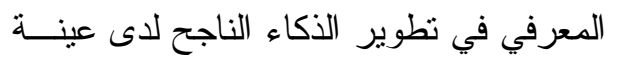

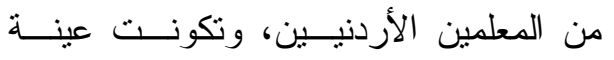


إدارة شرق المنصورة التعليمية، إدارة غرب

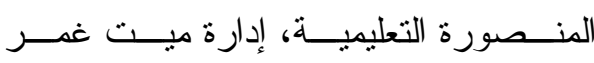

التعليمية، إدارة السنبلاوين التعليميــة، إدارة

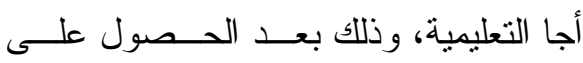

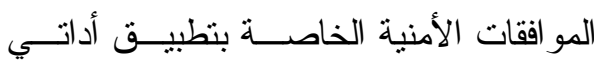
البحث. ثانيا: الأدوات المستخدمة في البحث:

1- مقياس الـــكاء الحيــاتي (إعـــاد

$$
\text { (الباحث). }
$$

قام الباحث بالاطلاع علــى مقــاييس

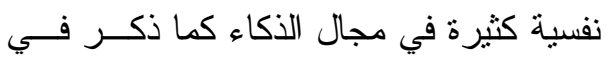

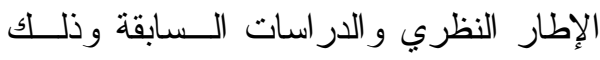

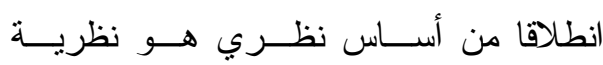

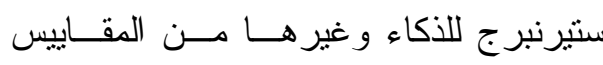
و النظريات و النزجمات الأخرى كي بـستفيد

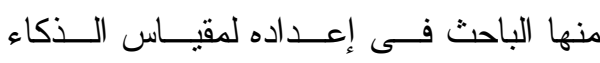
الحياتي في الدر اسة الحالية.

ور اعى الباحث في صياغة المفردات مناسبة التعريف الإجرائي المحدد لكل بعـد إعـ

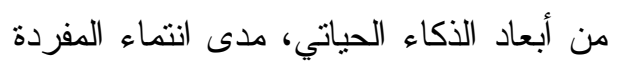

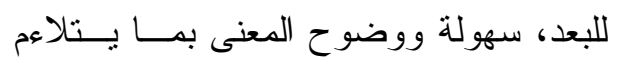
وطبيعة العينة الحالية، فقد تم صياغة (lov) مفردة، (0) مو اقف حياتية ضمن البعد الأول

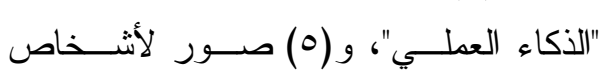

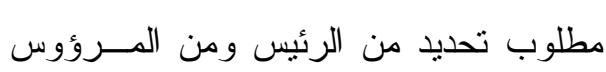
فيها ولماذا؟ ضمن البعد الخــامس "الــــكاء ولـاء

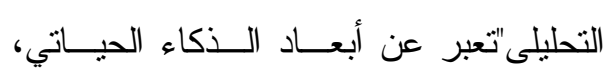

البحوث السابقة فيما يلي: لم تتتاول البحــوث السابقة طبيعة معوقات الذكاء الحياتي ولم يتم تتاولها مع متغير ات أخرى، عدد من البحوث اعتمد على عينات صغيرة الحجم، لم تنتاول

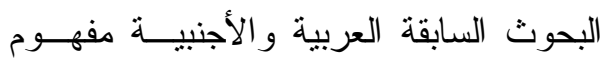
الذكاء ومعوقاته في نفس الوقت في دراســــة واحدة.

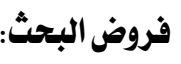

في ضوء مشكلة البحث و الدر اســات

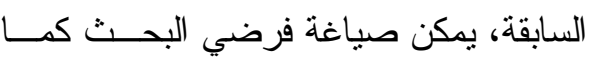
يلي: - توجد فروق دالة إحصائيا بين متوسطات درجات الذكاء الحياتي لـــــ المعلمــين

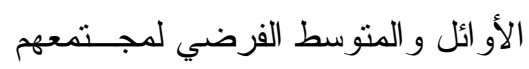
في أبعاد الذكاء الحياتي.

- توجد فروق دالة إحصائيا بين منوسطات بـات

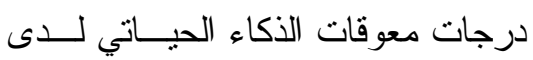

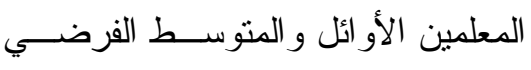

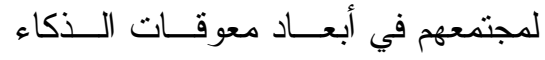
الحياتي.

\section{منهجية البحث وإجراياته:} أولا: عينة البحث: تكونت عينة البحث من (9VY) مــن

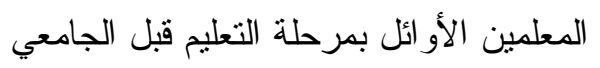

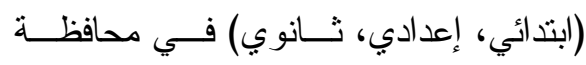
الدقهلية بجمهورية مصر العربية. ونم تطبيق إعبية

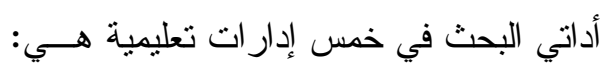


ارتباط درجة كل بعد من أبعاد مقياس الذكاء

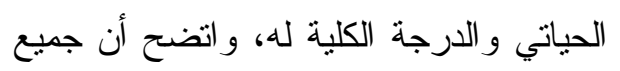

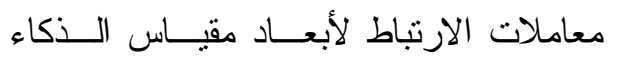

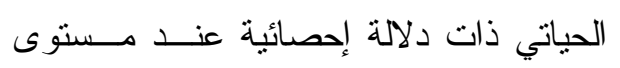

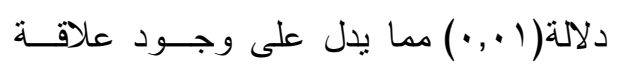

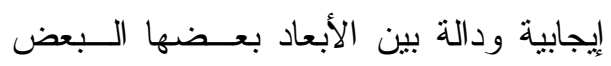
و الارجة الكلية للمقياس. الصدق العاملي:

قام الباحث بالتحقق من صدق المقياس بطريقة الصدق العاملي بإيجاد نتبع مفردات

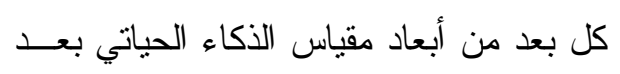

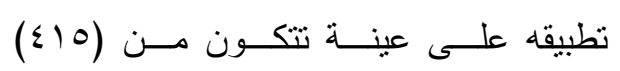

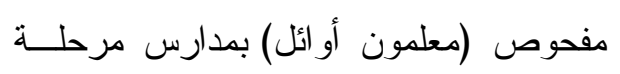

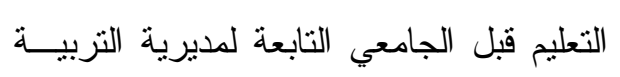

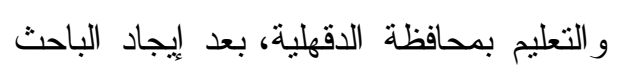

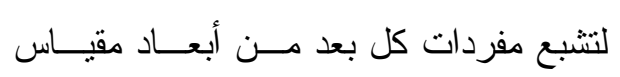

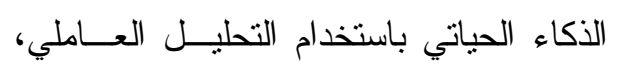

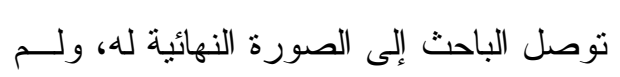

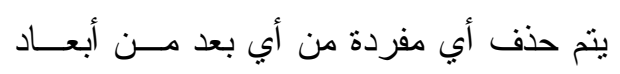

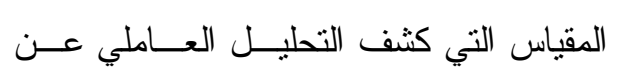
بقائها أحد عشر عاملا (ستة ذكاءات وخمسة أساليب تفكير ) كعو امل ثابتة للذكاء الحيــاتي

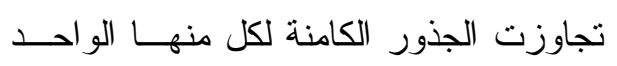
الصحيح كما يتضح من جدول( (1) التالي.
شكلت فى مجملها الصورة الأولية للمقيــاس،

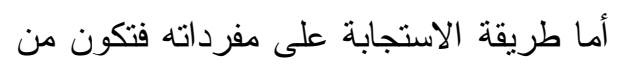
خلا اختيار أحد البدائل (تتطبق على (تماما،

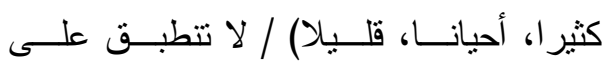
(إطلاقا").

\section{صدق المحكمين: تم عرض المقياس}

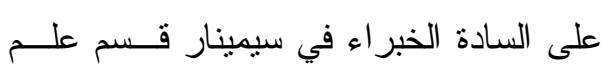

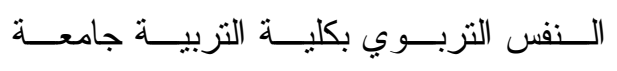

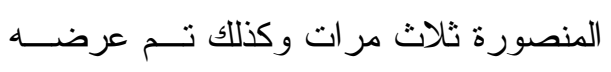
على عدد من السادة المحكمين من أساتذة علم النفس التزبوي و الصحة النفسية في جامعات

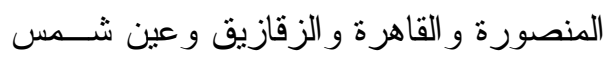

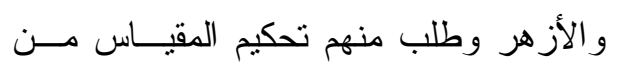

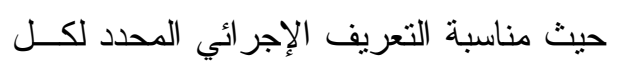

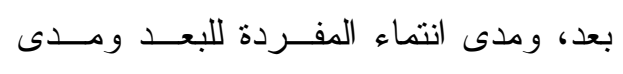

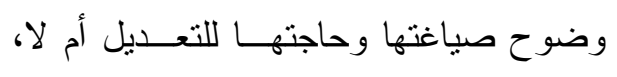

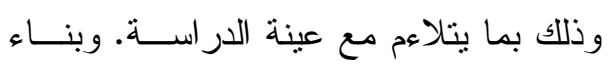

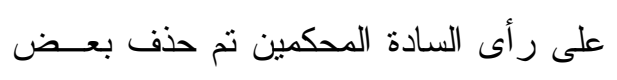
المفردات التي قلت نسبة الاتفاق عليها عـن $\% \wedge 0$ وقام الباحث بحساب الاتساق الداخلي

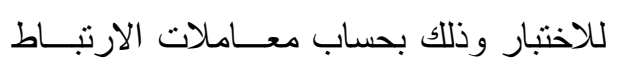
بين مفردات كل بعد من أبعاد مقياس الـــكاء

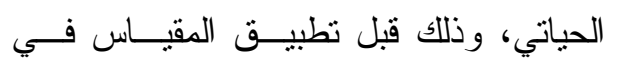

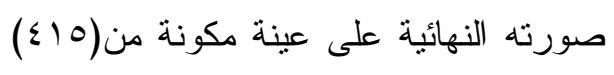
مفحوص، كما قام الباحث بحساب معساملات 
جدول(1) الجذور الكامنة ونسب التباين لأبعاد مقياس الأكاء الحياتي.

\begin{tabular}{|c|c|c|c|c|c|c|c|c|c|c|c|}
\hline \multicolumn{11}{|c|}{ العوامل المكونة لمقياس الذكاء الحيتي } & \\
\hline 11 & 1. & 9 & $\wedge$ & v & 1 & $\bullet$ & $\varepsilon$ & $r$ & r & 1 & \\
\hline ץ, צ & Y, 79 & $r, v V$ & $\uparrow, १ \wedge$ & $r, \cdot+$ & $r, \varepsilon r$ & $r, 01$ & $r, 9 \mathrm{~V}$ & L & $\varepsilon, v$. & $0, .0$ & الجذر الكامن \\
\hline 1,09 & $1, v_{1}$ & $1, \mathrm{~V}$ & $1, \Lambda r$ & 1,94 & 1,99 & $r, .0$ & r,0 & $r, \cdot v$ & $r, \leqslant r$ & $V, r$. & نسبة التباين\% \\
\hline
\end{tabular}

لاى المعلمين الأوائل، فلذلك وجــب تتويــع ثبات مقياس الأكاء الحياتي:

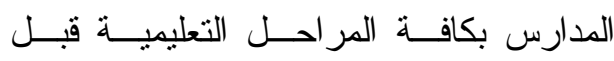

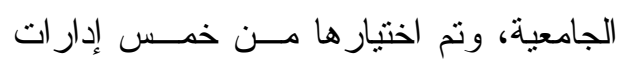

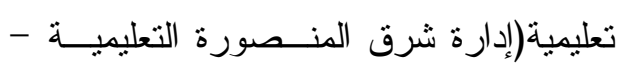

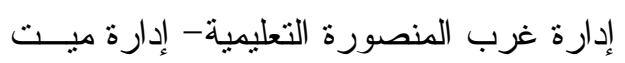
غمر التعليمية - إدارة السنبلاوين التعليميـــة-

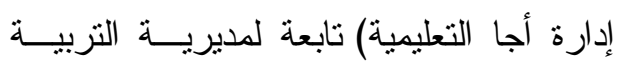

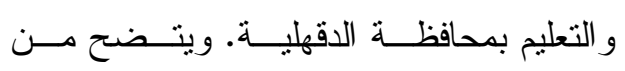
جدول(ץ) التالي معاملات ثبات أبعاد مقيــاس ولثة الأكاء الحياتي.

قام الباحث بالتحقق من ثبات مقياس

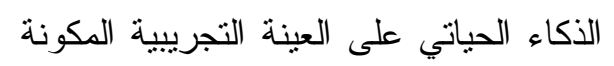

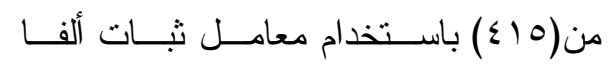

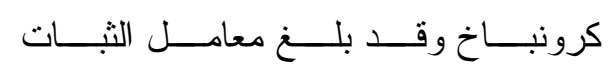
للمقياس(9 , ·). ونم اختيار أفر اد العينة مــن ولن

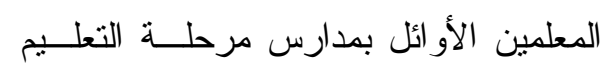

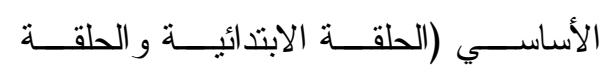
الإعدادية) وكذلك بمدارس المرحلة الثانوية

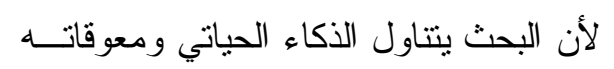
جدول(r) معاملات ثبات كل بعد من أبعاد مقياس الأكاء الحياتي.

\begin{tabular}{|c|c|}
\hline معامل ثبات ألفا كرونباخ & الأبعاد \\
\hline$*, V \leq V$ & الذكاء العملي \\
\hline$*, V \leq \varepsilon$ & الذكاء اللغوي \\
\hline$*, V \leqslant V$ & الذكاء الاجتماعي \\
\hline$*, 79 \mathrm{~V}$ & الذكاء الانفعالي/الوجداني \\
\hline$*, 771$ & الذكاء التحليلي \\
\hline$*, V Y \leq$ & الذكاء المنطقى الرياضياتى \\
\hline$*, 709$ & أساليب التفكير (أسلوب تفكير التو افق و التغيير) \\
\hline$*, 7.9$ & أساليب التفكير (أسلوب التفكير التحليلي) \\
\hline$*, 0 \ldots$ & أساليب التفكير (أسلوب التفكير الإبداعى) \\
\hline$*, 0 \leq 7$ & أساليب التفكير (أسلوب التفكير التنفيذي) \\
\hline$*, 770$ & أساليب التفكير (أسلوب التقكير الاجنماعي) \\
\hline$*, \wedge \vee$. & الدرجة الكلية لمقباس الذكاء الحياتي \\
\hline
\end{tabular}




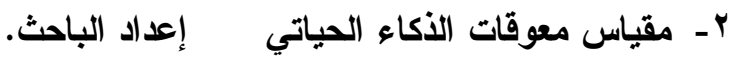
مفحوص. النهائية علـى عينــة مكونــة مــن (Yo.) قام الباحث بتحديــــ أبعــاد مقيــاس معوقات الذكاء الحياتي كما بتضمنها المقياس قام الباحث بايجاد الــصدق العـاملي الحالي بناء على الإطار النظري الذي تتاول

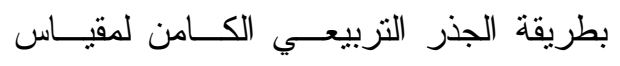

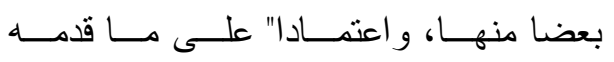

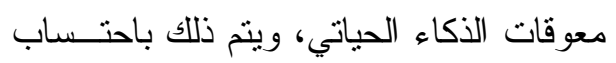

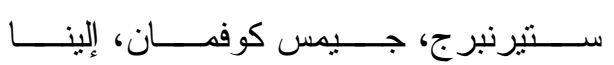

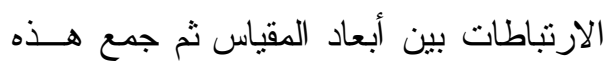

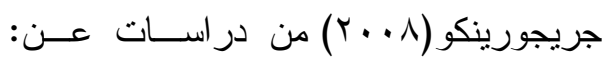

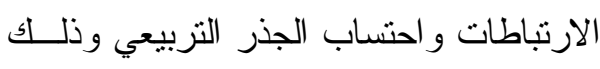

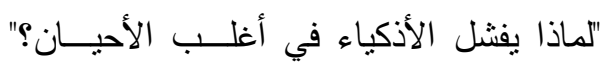

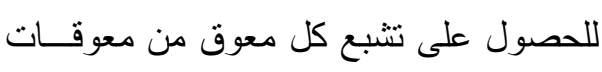

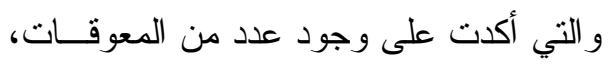

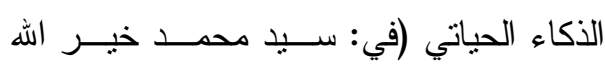
تم جمعها ليلغ عددها • r معوقا، قام الباحث

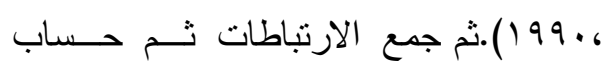

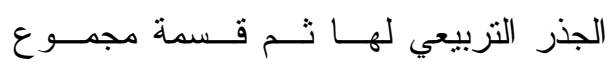

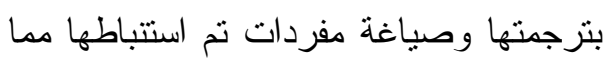
نم ترجمته ثم عرضها على السادة الأسـاتذة

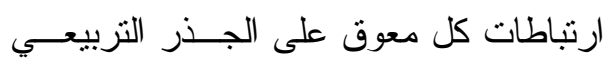

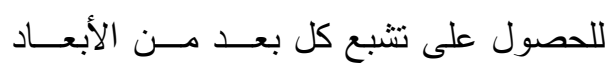

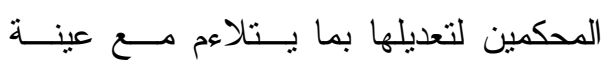

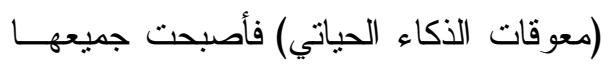
أكبر من(Yo, · •) وهي تشبعات مرتقعة، وهذاه

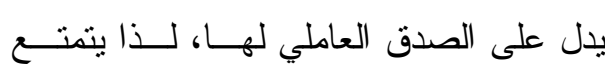
المقياس و أبعاده بدرجة مناسبة من الصدق. وقام الباحث بالتحقق من ثنات مقياس

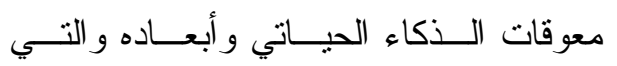
تتضمن: نقص الدافعية، نقص ضبط الدوافع، نقص المثابرة//المثنابرة المفرطـــة، اســتخدام

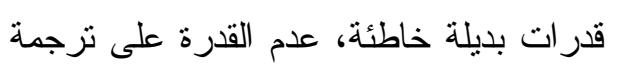
الفكر إلى سلوك، نقص التكيف مع الظروف و الأوضاع المحيطة، عدم القدرة على إكمال

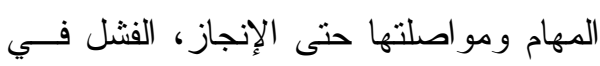

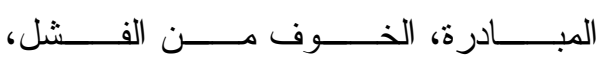

$$
\text { الدر اسة. }
$$

وتم عرض المقيــاس علــى الــسادة

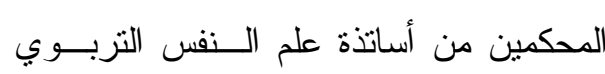
وطُب منهم تحكيم المقياس من حيث مناسبة

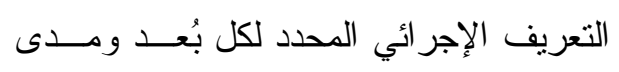

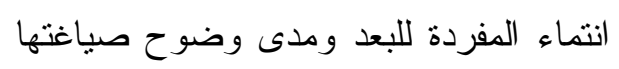

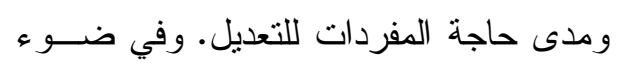

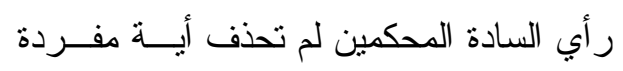
حيث كانت نسبة اتفاق لجميع المفردات أكبر من \%9 \% \% وقــام الباحــث بحسـساب معــاملات الارتباط بين مفردات كل بُعـــد مــن أبعــاد

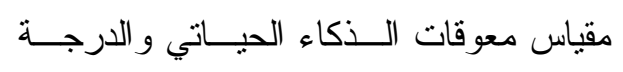

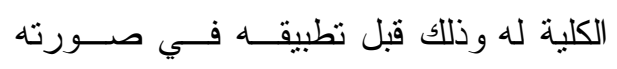




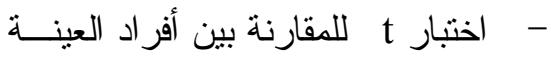

$$
\begin{aligned}
\text { توائج البحث ومناقشتها: } & \text { و المجتمع الافتر اضي لهاء }
\end{aligned}
$$

يعرض الباحث فيما يلي نتائج اختبار

فروض البحث، ثم تفسير ها في ضو ء الإطار

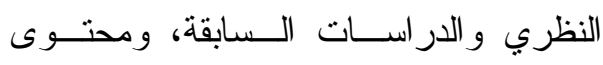

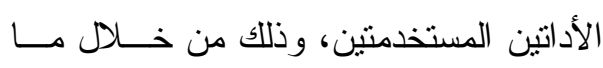

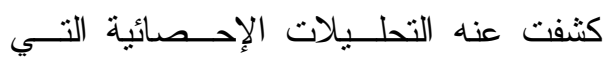

استخدمت لاختبار الفروض و التحقق منها.

1 - وصف نتائج اختبــار الفــرض الأول

$$
\text { وتفسيرها: }
$$

ينص الفرض الأول للبحث على أنه:

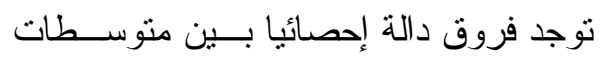

درجات الذكاء الحياتي و أبعاده لاى المعلمين

الأو ائل و المتوسط الفرضي لمجتمعهم.

وللتحقق مــن هــذا الفــرض الأول

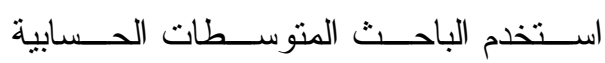

و الانحر افات المعيارية وقيمـــة(t).وجــــاءت

النتائج كما يوضحها جدول (r) الذي يوضح

نتائج قيمة t لأبعاد الذكاء الحياتي.
التسويف (الإرجاء أو المماطلة)، عدم توجيــه اللوم إلى النفس، الإشفاق المفرط على الذات، الأرجاء

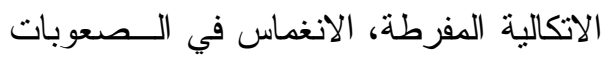

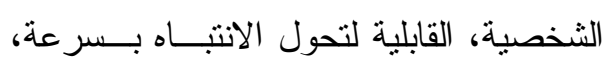

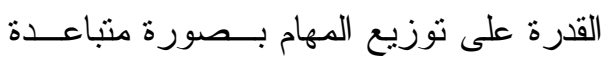

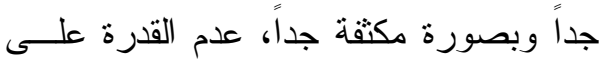

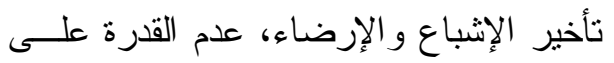

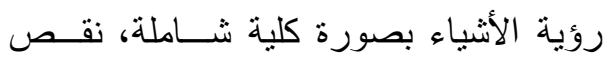
النوازن بين التفكير الناقد و التحليلي و التفكير

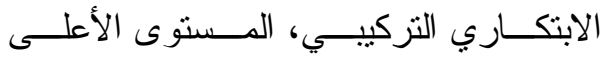

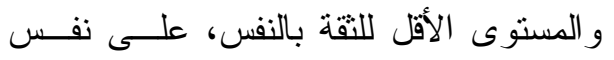

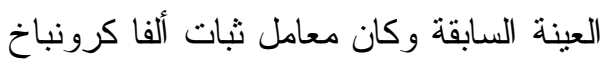

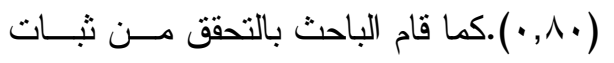
مقياس معوقات الـــكاء الحيــاتي باســـتخدام معامل ثبات التجزئة النصفية الذي تم حسابه

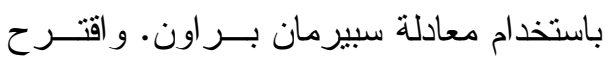
سبيرمان براون معادلة للتصحيح الإحصائي

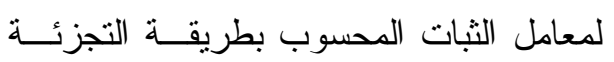
النصفية. ثالثا: الأساليب الإحصائية المستخدمة فــي

$$
\text { البحث: }
$$

- - المتوسطات الحسابية. - - الانحر افات المعيارية. 
جدول(ץ) قيمة t لأبعاد الأكاء الحياتي لاى المعلمين الأوائل بمرحلة التعليم قبل الجامعي

\begin{tabular}{|c|c|c|c|}
\hline \multicolumn{4}{|c|}{. $(q \vee Y=\dot{U})$} \\
\hline قيمة t & الاتحر افات المعيارية(SD) & المتوسطات(X) & أبعاد الأكاء الحياتي \\
\hline$* 1 \mu 9,0 \wedge$ & $T, \wedge \mathrm{r}$ & $r \cdot, 0 \leqslant$ & الأكاء العملي \\
\hline * I T r V & ᄀ,А & $Y 9,77$ & الأكاء اللغوي \\
\hline * & $v, \cdot \Lambda$ & Y৭,人т & الأكاء الاجتماعي \\
\hline$* 1 \Gamma_{0}, \leq 0$ & $7, \wedge \vee$ & rq,^. & الأكاء الاففعالي/الوجداني \\
\hline$* 10 \mathrm{~V}, 1$. & $7,9$. & $r \varepsilon, V T$ & الأكاء التحليلي \\
\hline$* 1 \leq r, 9 \mu$ & $7, r \wedge$ & rᄉ, qr & الأكاء المنطقى الرياضياتى \\
\hline$* 1 \leqslant 9, .9$ & 7,11 & rq,or & أسلوب تفكير التو افت والتغيير \\
\hline$* 10 \mathrm{~V}, \cdot 7$ & $0, \mu_{1}$ & $r \uparrow, V$. & أسلوب التفكير التحليلي \\
\hline$* 101,71$ & $\varepsilon, \wedge \Gamma$ & $r r, 0$. & أسلوب التفكير الإبداعي \\
\hline$* 10 \leqslant, \wedge \varepsilon$ & 0,19 & $r 9,11$ & أسلوب التفكير التنفيذي \\
\hline$* 1 \leq q, r \leq$ & $0, V \pi$ & $r V, \Sigma T$ & أسلوب التفكير الاجتماعى \\
\hline
\end{tabular}

درجات أبعاد الــذكاء الحبــاتي و المتوســـ * القيم دالة عند مستوى دلالة(1 + , •). الفرضي لمقياس الذكاء الحيــاتي. ويمكـن واستخدم الباحث المعادلة التالية في إيجاد تفسير هذه النتيجة بأن أبعاد الذكاء الحيــاتي ظاهرة لدى أفر اد العينة بـصورة كبيــرة . ويمكن تفسير ذلك بأن الذكاء العملي يتمثــل في تحديد السلوكيات النى تعد ذكية في ثقافة

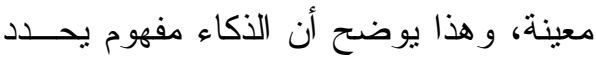
ثقافيا، فهو ينعكس في الإدارة العملية لثؤون

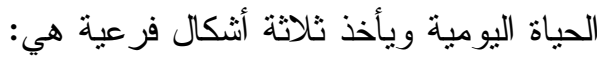

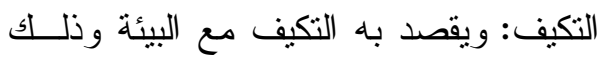
من خلال تعلم العادات و التنظيمـات التــي توجد في البيئة الجديدة ويأخذ اشكالا مختلفة في الثقافات المختلفة. الانتقاء: ويقـــد بــــ

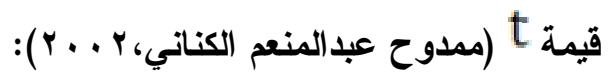

$$
t=\frac{x_{1}-x_{2}}{\sqrt{\frac{S_{1}^{2}}{n_{1}}+\frac{S_{2}^{2}}{n_{2}}}}
$$$$
\text { وحيث إن } \propto \text { وحفر }
$$
فإن المعادلة تصبح كما يلي:

$$
t=\frac{x_{1}-x_{2}}{\sqrt{\frac{S_{1}^{2}}{n_{1}}}}
$$

يتضح من جـدول(r) أن قيمــة

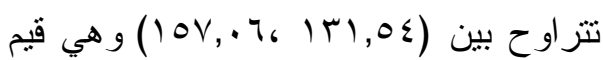
دالة عند مستوى (1 +, •) حيث إنها أعلى من قدرة الفرد علــى انتقـــاء و اختيـــار البيئــة القيمة الحرجة وهي (197, (1)، وقد اســتخدم

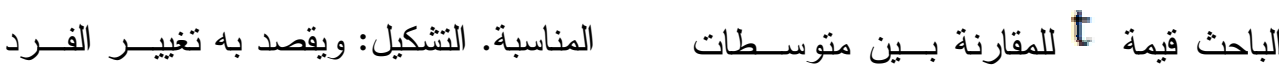




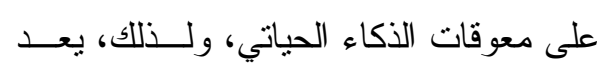
الذكاء اللغوي عــاملا أساســيا فــي نجـــاح التعاملات اليومية و إيصـال ما يريـــده الفــرد لنآخرين.

وفيما يتعلق ببعد الذكاء الاجتمــاعي،

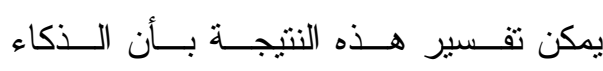
الاجتماعي برتبط بما لدي الفرد من مهار ات مرتبطــــة بإحسـساسه باحتياجــات الآخــرين ورغباتهم، وصدقه معهم و اهتمامـــه بالبيئــة

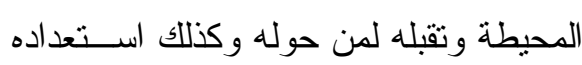

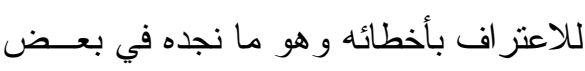
المعوقات وخاصة معوق عدم توجيه اللــوم إلى النفس بطريق سلبية بمعنـى أن هنــالك

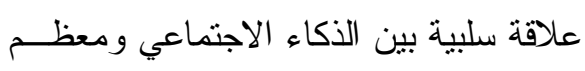
معوقات الذكاء التي لا تظهر إلا عند التعامل مع الآخرين و المو اقف الحياتية اليومية.

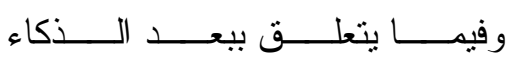

الانفعالي/الوجداني، يمكن تفسير هذه النتيجة

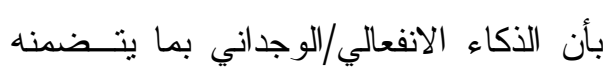

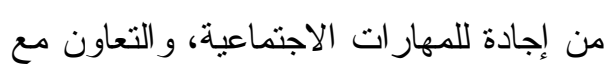
الزملاء، و القدرة على اســتيعاب وجهــات

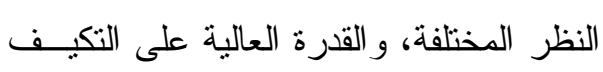

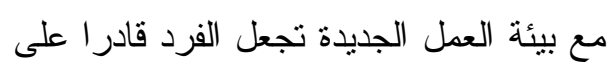

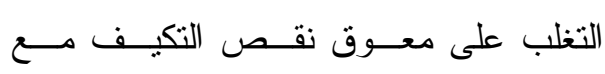

للبيئة ويفيد هذا عندما يكون من غير الممكن تحقيق التكيف مع البيئة أو انتقاء بيئة جديدة. ويتميز الفرد الذي يتسم بهذا النوع من الذكاء بأنه يكون قادرا وبشكل خاص على النطبيق

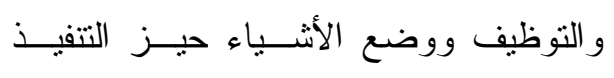

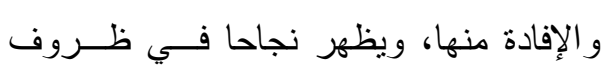

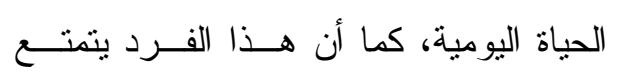
بالمعرفة اللازمة للنجاح في الحياة اليوميـــة

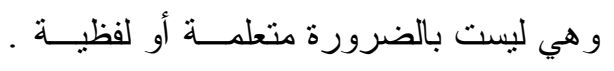

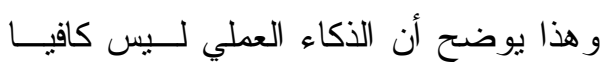

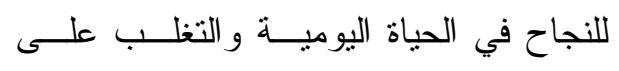

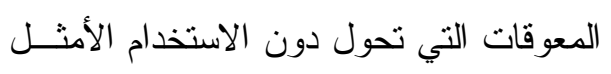
لذكاء الفرد.

وفيما يتعلق ببعد الذكاء اللغوي، يمكن

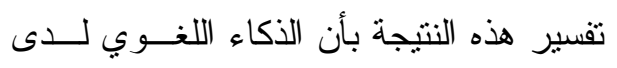
المعلمين الأو ائل يكون فــي مـستوى عــــال بحيث يستطيعون التعبير بدقة وبطلاقة عـن مـن ما يقدمونه من مقرر ات در اسية لطلابهم في لئي

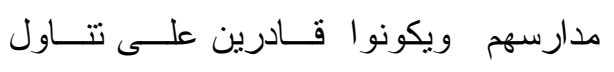
ومعالجة و استخدام اللغة ومعانيها في المهــام

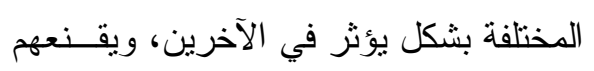

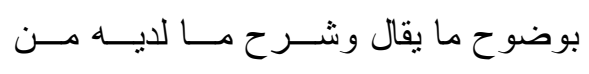
معلومات، كما أن الأفر اد الذين يتمتعون بهذا الذكاء يكون لديهم القــدرة علــى اســـتخدام الكلمات بكفاءة شفوية و هذا يساعد في التغلب 
وفيما يتعلق ببعـــــــــــاء المنطقـي

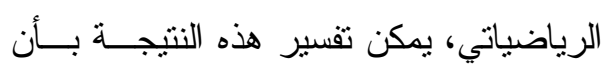

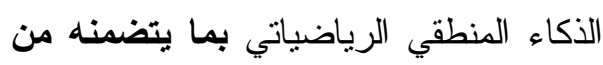

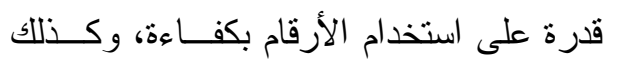

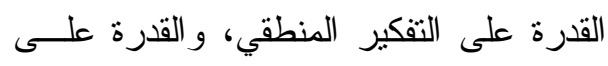

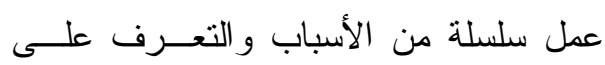
النماذج وتصنيفها، كما أنه يتمثل في القـدرة

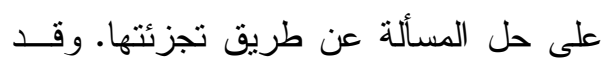

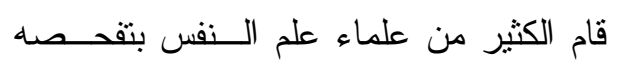
و استقصائه، وتوجد مناطق في الدماغ تعتبر

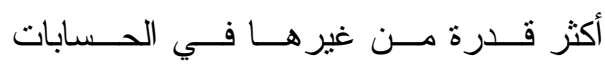

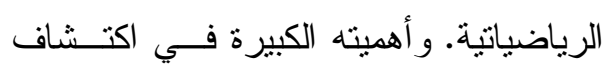
النماذج وتتبع التسلسلات المنطقية وإجــر اء ولهياء

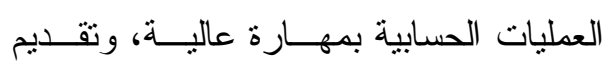
مجموعة مــن القــدرات و الاســتر اتيجيات و الأنشطة التي يمكن استخدامها في المجــال التزبوي لزيادة الفاعلية التعليمي بما يجعـل لــل الفرد قادر ا على النغلب على معوقات الذكاء لتهاء

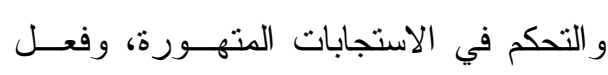
الأثنياء بدون ضغط سو اء كان خارجيــا أو لون مفروض من قبل المرء نفسه حتى لا يتخــذ التسويف أسلوب في التعامـلـ مـــع المهــام المختلفة.

وفيما يتعلق ببعد أســاليب التفكيـرـ، ، يمكن تفسير هذه النتيجة بأن أساليب التفكيـر
الظروف والحقائق و الأوضاع الذي يـــتنط بفقدان الحماس عند إتمام المهام.

وفيما يتعلق ببعد الـــكاء التحليلــي،

يمكن تفسير هذه النتيجة بأن الذكاء التحليلــي لئي يتضمن القدرة على التحليل و إصدار الأحكام

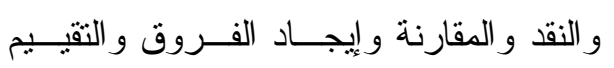

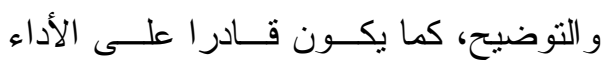
بشكل مميز في المدرسة و على الاختبــار ات

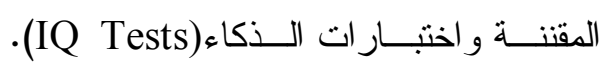
وهؤ لاء الأفر اد الذين يتمتعون بهذا الذكاء يتم وصفهم بأنهم مو هوبون في المدارس، وطبقا

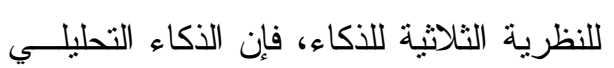

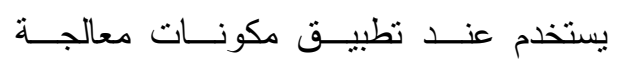

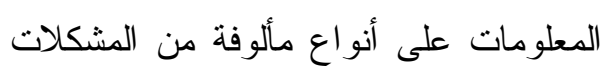

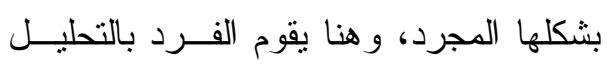

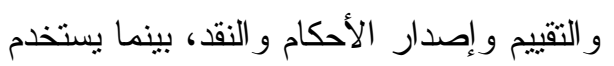

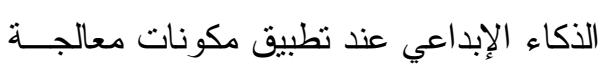
المعلومات على أنماط جديدة من المشكلات،

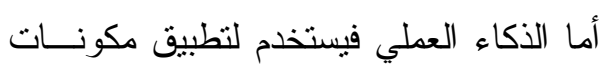
معالجة المعلومات علــى مـشكلات الحيــاة اليومية، و هنا على الفرد أن يطبق، ويسـستقيد من الأشياء ويوظفها ويضعها ضمن السياق،

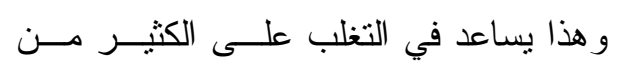

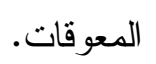




$$
\begin{aligned}
& \text { تعد عاملا مهما جدا عند تكــوين علاقــات الأداء بصورة جيدة فيها ، وبناء على هــذا، }
\end{aligned}
$$

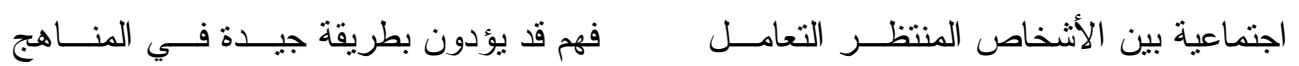

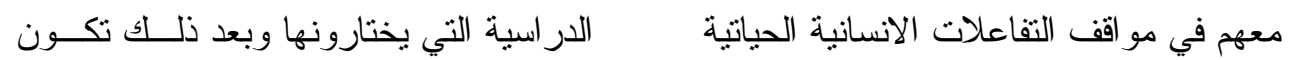

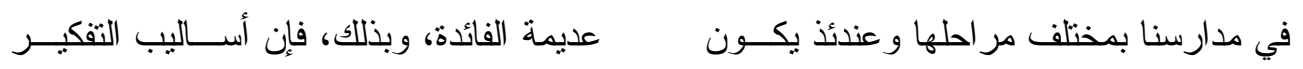

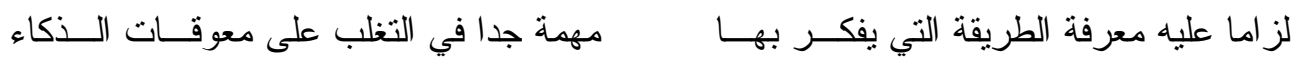

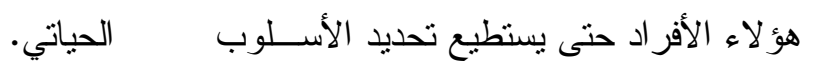

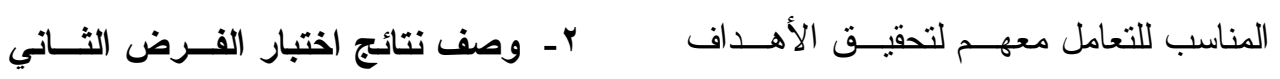

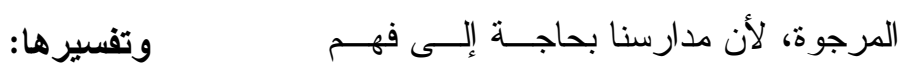

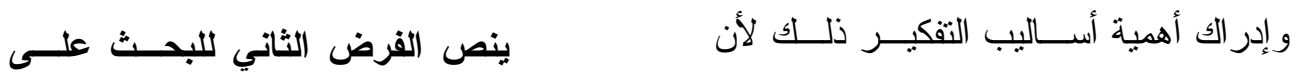

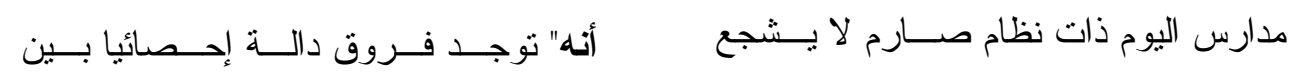

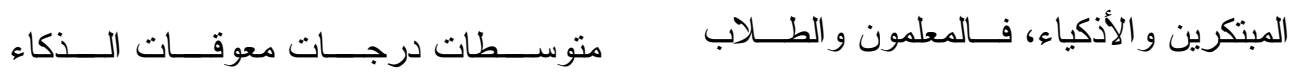

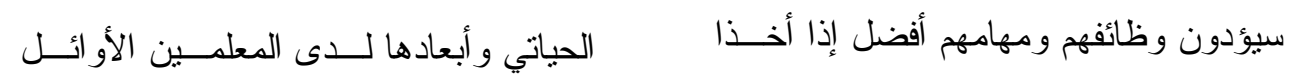

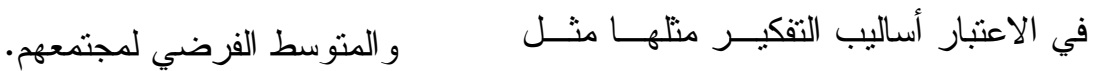

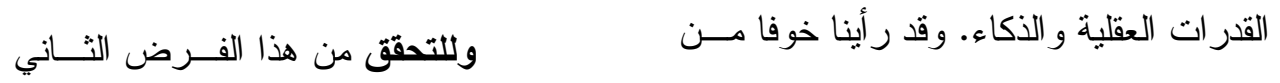

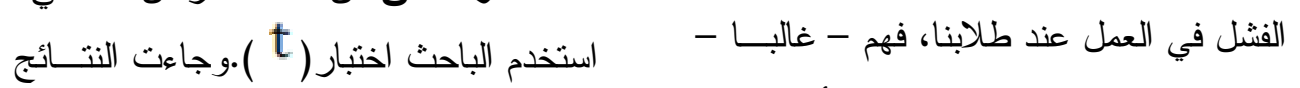

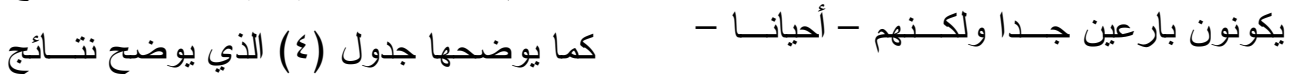

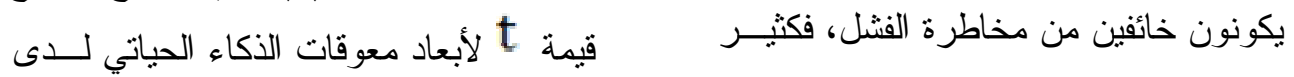

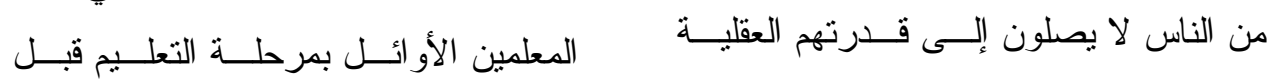

$$
\begin{aligned}
& \text { الكاملة بسبب خوفهر من الفثل فيما يفعلون، الجامعي. } \\
& \text { وفى الجامعة لا يأخذون المنــاهج الدر اســـية }
\end{aligned}
$$

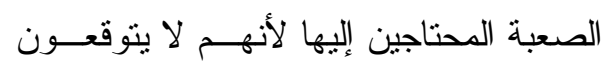


جدول(ع) قيمة t لأبعاد معوقات الأكاء الحياتي لاى المعلمين الأوائل بمرحلة التعليم قبل

\begin{tabular}{|c|c|c|c|}
\hline قيمة t & $\begin{array}{c}\text { المعيارية(ألفات(SD) } \\
\text { (SD) }\end{array}$ & 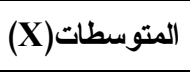 & أبعاد معوقات الأكاء الحياتي \\
\hline$* 1 \leqslant 9,47$ & $r, \Sigma \Gamma$ & 11,70 & نقص الدافعية \\
\hline *10 $, 1,7$ & r,rV & 11,71 & نقص ضبط الدو افع \\
\hline$* 119,17$ & r,OY & $11, r$ & نقص المثابرة/المثابرة المفرطة \\
\hline$* 1 \leq \Lambda, Y Y$ & $Y, \sum Y$ & $11, \Sigma \Lambda$ & استخد ام قدر ات بديلة خاطئة \\
\hline$* \mid \leq r, V \backslash$ & $r, \leqslant 0$ & $11, \mathrm{r}$ & عدم القدرة على ترجمة الفكر إلى سلوك \\
\hline * $) \leq r, r$. & $r, \leqslant q$ & $11, \mathrm{rV}$ & نقص التكيف مع الظروف و الأوضاع المحيطة \\
\hline$* 1 \leqslant Y, 90$ & $r, \leqslant q$ & 11,10 & عدم القدرة على إكمال المهام ومو اصلتها حتى الإنجاز \\
\hline$* 1 \leq 9,10$ & $r, r q$ & 11,10 & الفنشل فى المبادرة \\
\hline$* 1 T V, 7 Y$ & Y,OV & $11, r \varepsilon$ & الخوف من الفثل \\
\hline *) $\leqslant \vee, \varepsilon \varepsilon$ & $r, \varepsilon \varepsilon$ & 11,0 & التسويف (الإرجاء أو المماطلة) \\
\hline$* 1 \leq V, 0$. & $r, r \Lambda$ & $11, Y 1$ & عدم توجيه اللوم إلى النفس \\
\hline$* 1 \leq 0, V \mathrm{~V}$ & $r, \Sigma \varepsilon$ & $11, \mathrm{rV}$ & الإشفاق المفرط على الذات \\
\hline$* 1 \leqslant 0,7 \varepsilon$ & $r, \varepsilon r$ & 11,14 & الاتكالية المفرطة \\
\hline * $\mid r V, 乏)$ & r,07 & $11, Y \leq$ & الانغماس في الصعوبات الثخصية \\
\hline$* 1 \Gamma q, 9$. & $r, 0 \leqslant$ & 11,14 & القابلية لتحول الانتباه بسر عة \\
\hline *।人ฯ,0. & T, rV & 11,19 & مكثقة جدا على توزيع المهام بصورة منباعدة جدا وبصورة \\
\hline *IM, M纟 & r,OY & 11,10 & عدم القدرة على تأخير الإشباع و الإرضاء \\
\hline$* 1 \Gamma \varepsilon, 9 \mu$ & $Y, 7)$ & $11, \mathrm{r} \Lambda$ & عدم القدرة على رؤية الأشياء بصورة كلية شاملة \\
\hline$* 1 \leqslant 9, \varepsilon V$ & t, Th & 11,11 & الابتكاري التنز كيبي التنكير الناقد و التحليلي و التفكير \\
\hline$* 1 \Gamma \varepsilon, 97$ & $r, 00$ & $11, \cdot \varepsilon$ & المستوى الأعلى و المستوى الأقل للثقة بالنفس \\
\hline
\end{tabular}

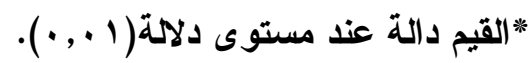

وتو اجه حتى الأفر اد الأكثر ذكاء، وفى أغلب

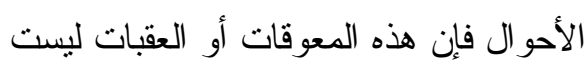

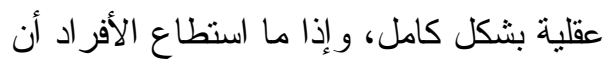

يتحكمو ا في منل هذه الأنو اع من المشكلات،

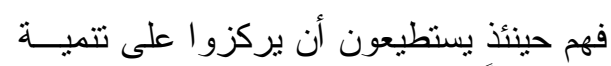

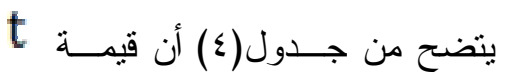

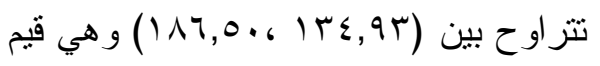

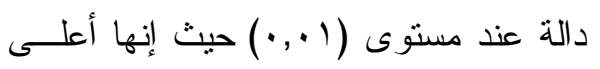

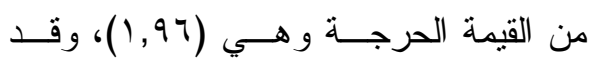

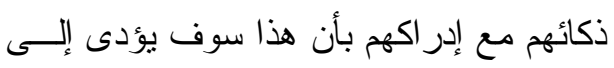

استخدم الباحــث قيمــة t للمقارنـــة بــين

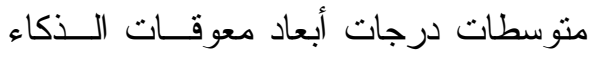

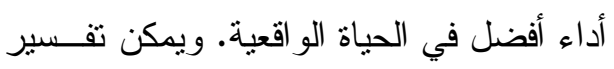

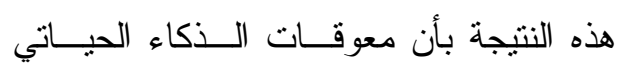
الحياتي و المتوسط الفرضي لمقياس معوقات

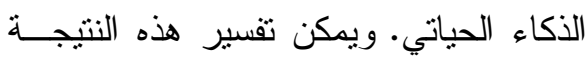

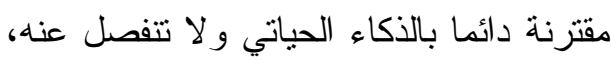

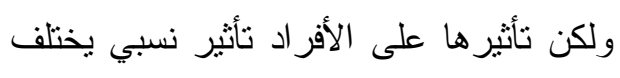

بأن أبعاد معوقات الذكاء الحيــاتي ظـــــاهرة

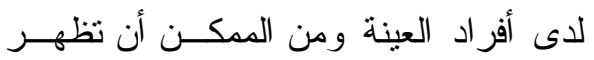


عو امل معقدة تزتبط بالسياق المحيط بـالفرد

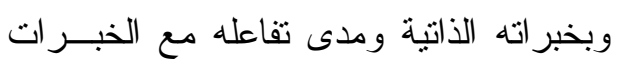
الحياتية اليومية. التطبيقات التربوية لنتائج البحث: من النتائج التي تم التوصل إليها فــي

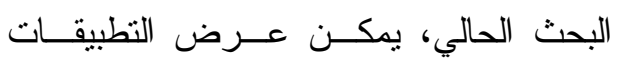
التزبوية لتلك النتائج كما في جدول(0) التالي:

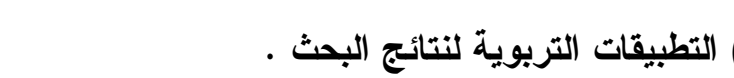

جدول(0)

\begin{tabular}{|c|c|}
\hline التطبيقات التربوية لها & نتائج البحث \\
\hline 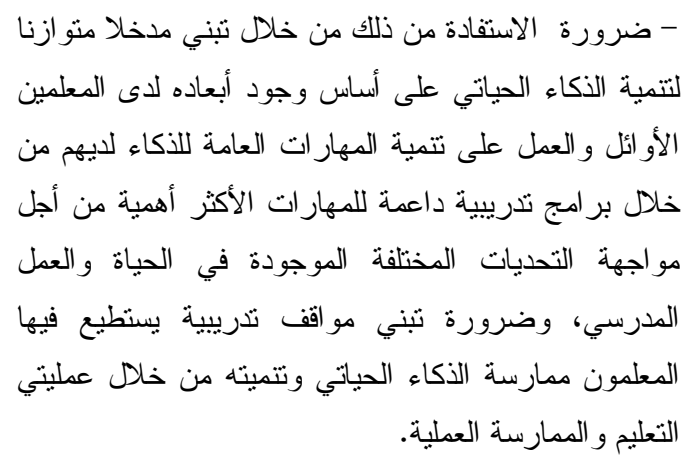 & 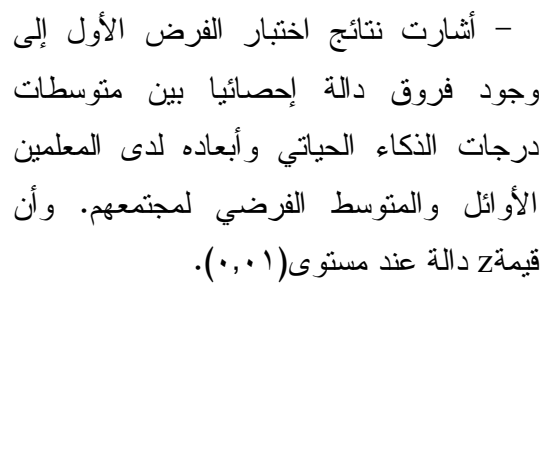 \\
\hline 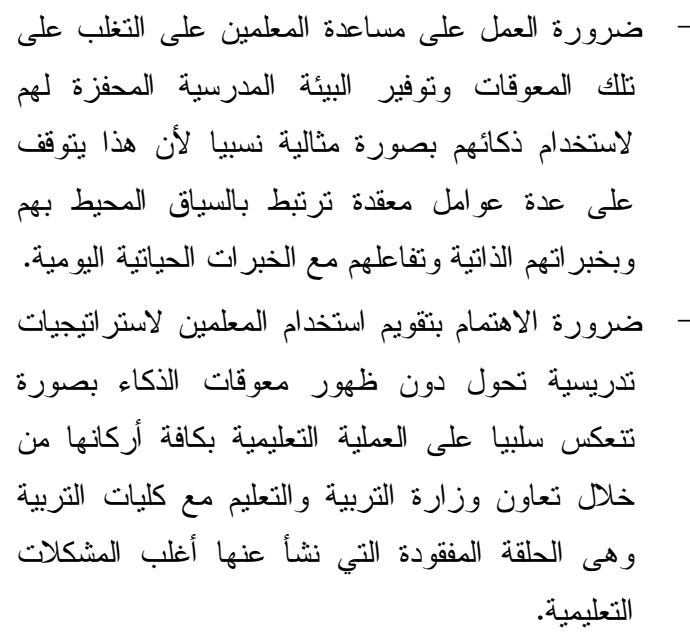 & 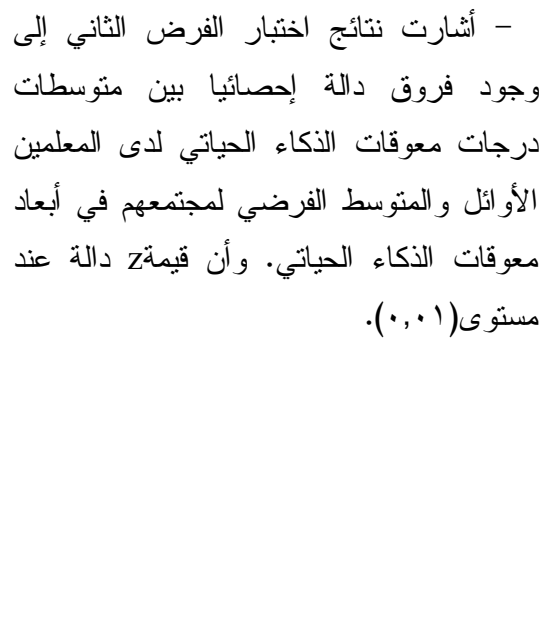 \\
\hline
\end{tabular}

من فرد لآخر، فهنالك أفــر اد تـسنطيع أن تتخلب عليها وتعيق ظهور ها وتأثثر ها مدـــا يجعلهم يستخدمون ذكاءهم بصورة مناليــة

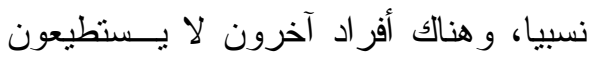

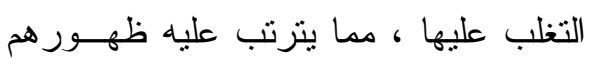
بصورة لا تعكس المستوى الفعلي لذكائهم.

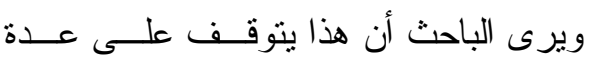


العامة في الأردن وعلاقتها بالانضباط المدرسي لدى الطلبة وتفاعل المدرسة مع المجتمع المحلي، رسالة دكتوراه غير منشورة، جامعة عمان الربية للار اسات العليا، الأردن. - - سعيد عبد الغني سرور( ع . . r). أنماط التفكير وفق النموذج الثامل للمخ عند نيد هيرمان وعلاقتها بالذكاء المتعدد

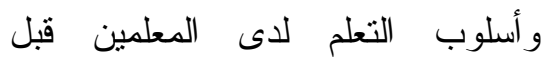
الخدمة، مجلة البحوث النفسية والتريوية، كلية التزبية، امعة المنوفية، العدد الثالث، المجلد التاسع

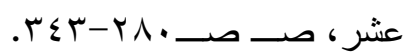
-

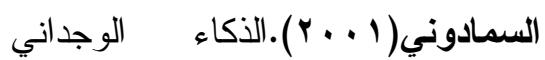
و التوافق المهني للمعلم، دراسة ميدانية على عينة من المعلمين و والمعلمات بالتعليم الثانوي العام، مجلة علئ عالم

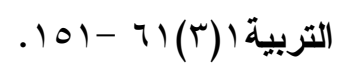
- سيد محد خيرالله(.99 1). بحوث نفسية وتربوية، الطبعة الثانية، بيروت، دار النهضة العربية.

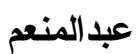
-

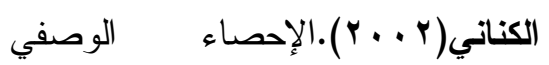
و الاستدلالي في العلوم النفسية و التربوية
بحــوث مقترحسة: يمكـن وضـــع بعـض المقترحات بإجراء بعض البحوث من بينها: 1- بحوث حول بعض البرامج التدريبية التي يمكن أن تساعد في تتمية الذكاء الحياتي. r- بحوث حول دور الذكاء الحياتي في النجاح في مجالات الحياة المختلفة. r- فاعلية برنامج تدريبي للتغلب على معوقات الذكاء الحياتي. ع - بحوث حول بعض الأنشطة المدرسية

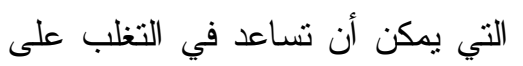

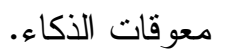

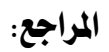
- أحلام الباز، مجدي قاسم، حين محمود (11 (Y). المستويات المعيارية

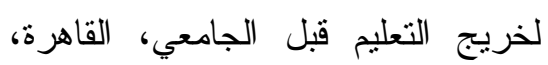
دار الفكر العربي.

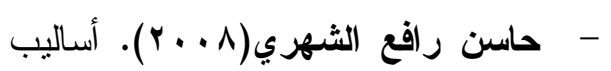
التفكير المفضلة في التذريس لاى معلمي ومعلمات التعليم العام بالمدينة المنورة،

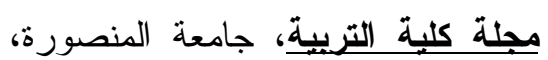
العدد الثامن و الستون، الجزء الثاني،

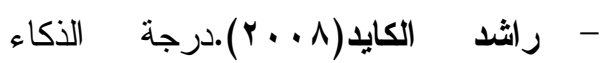
الاجتماعي لدى مديري المدارس الثانوية 
التريوية، المجلد الثاني و الأربعين، (r)،

$$
\text { صـ صـ }
$$

- Bourne, L.E. Strand, B. R. \& Dominowski, R. L.(1971).The Psychology of Thinking. N. J.: Prentice Hall Inc.

- Carlson, N. R. (1993).Psychology: The Science of Behavior( $4^{\text {th }}$ Ed.) USA: Allyn and Bacon.

- Epstein, S., and Meier, P., (1998). Integration of the Cognitive and the Psychodynamic Unconscious American Psychologist, 49(8), 624-709.

- Feldman, R. D. (1997).Essentials of Understanding Psychology( $3^{\text {rd }}$ ed.) New York :McGraw-Hill Inc.,260.

- Fitzgerald, J. M. \& Mellor, S. (1988).How do people think about intelligence? Multivariate Behavioral-Research; Vol. 23, No. (2), P.P. 143-157.

- Gardner, H. (1983).Frames of Mind: The Theory of Multiple Intelligences. New York: Basic Books.

- Goleman, D., (1984).Successful Executive Rely on own kind of Intelligence, The New York Times, July 31, C1, C11, P.1.

- Kirton, M. J. (1994). Adaptors and Innovators: Styles of

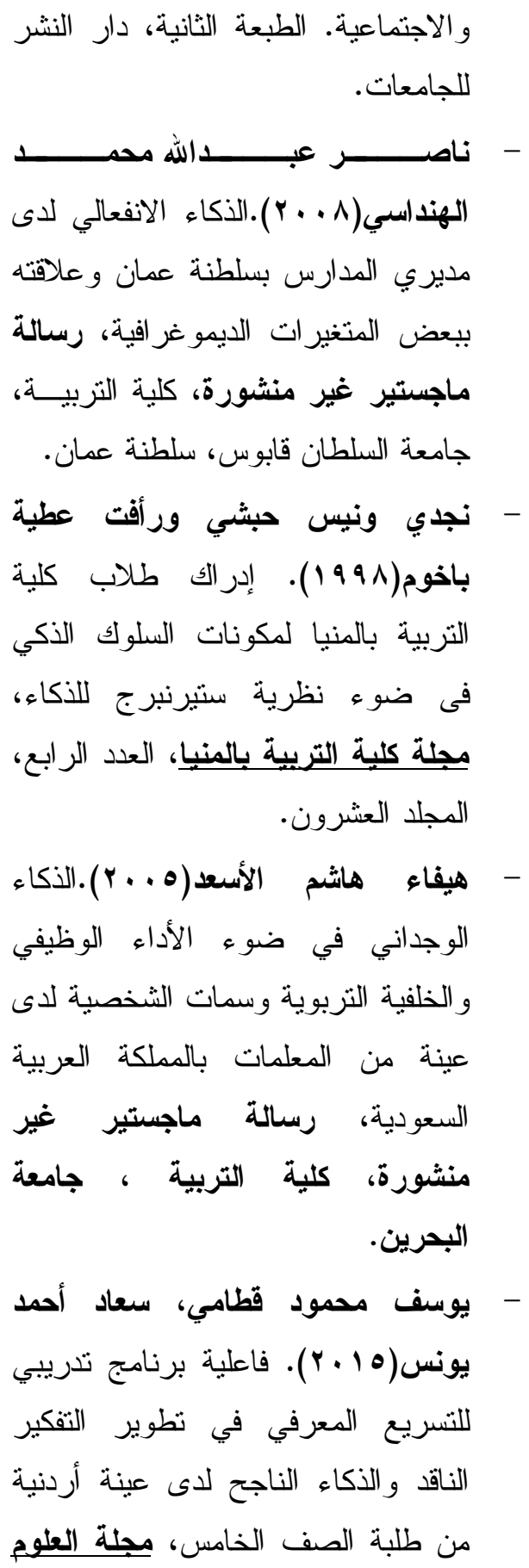


stressor, and symptoms in everyday life. Anxiety, stress, and coping, 10,269-303.

- Sternberg, R. J. (Ed.). (2000). Handbook of intelligence. New York: Cambridge University Press.

- Sternberg, R. J., \& Grigorenko E. L. (Eds.). (2002). The general factor of intelligence: Fact or fiction. Mahwah, NJ: Lawrence Erlbaum Associates.

- Sternberg, R. J. (2003).Wisdom, Intelligence, and Creativity Synthesized. New York: Cambridge University Press.

- Sternberg, R. J. (2006). The Scientific Basis for the Theory of Successful Intelligence. In R. F. Subtonic \& H. J. Walberg (Eds.) the Scientific Basis of Educational Productivity (pp. 161-184). Greenwich, CT: Information Age Publishing Co.
Creativity and Problem Solving, London; Routledge.

- Mayer, J. D., and Salovey, P.,(1997). What is Emotional Intelligence? In P. Salovey and D. J. Sluyter (Ed.), Emotional Development and Emotional Intelligence: Educational Implications. New York: Basic Books.

- Park, C.P., Moote, P. J., Turner, R.A., and Adler, N. E. (1997). The roles of constructive thinking and optimism in psychological and behavioral adjustment .Journal of personality and social psychology (73(3)-584-592).

- Perkins, D., (1995).Outsmarting IQ: The Emerging Science of Learnable Intelligence. New York, London: The Free Press.

- Sternberg, R. J., \& Lubart, T.I. (1995a). Defying the crowd: Cultivating creativity in a culture of conformity. New York: Free Press.

- Scheuer, E., and Epstein, S., (1997).Constructive thinking, reactions to a laboratory 